\title{
Microphytoplankton from middle palaeolatitudes of the Southern Hemisphere - a record from climate change strata of Baltica's O/S boundary
}

\author{
Monika MASIAK ${ }^{1}$, Marzenna STEMPIEŃ-SAŁEK² and Teresa PODHALAŃSKA ${ }^{3, *}$ \\ 1 momas@gazeta.pl \\ 2 University of Gdańsk, Faculty of Oceanography and Geography, Marszałka Piłsudskiego 46, 81-378 Gdynia, Poland \\ 3 Polish Geological Institute - National Research Institute, Rakowiecka 4, 00-975 Warszawa, Poland
}

Masiak, M., Stempień-Sałek, M., Podhalańska, T., 2020. Microphytoplankton from middle palaeolatitudes of the Southern Hemisphere - a record from climate change strata of Baltica's O/S boundary. Geological Quarterly, 64 (1): 86-103, doi: $10.7306 / \mathrm{gq} .1518$

In the present study, data on the diversity of acritarch and prasinophyte microphytoplankton were collected from Ordovician-Silurian transitional strata at three different geological localities in Poland: southern part of the Holy Cross Mountains (Małopolska Block, southern Poland), East European Platform (Baltica), and Koszalin-Chojnice Zone (NW Poland). The material represents the mucronata (trilobite) to vesiculosus (graptolite) biozones. The Ordovician microphytoplankton assemblages are characterized by low frequency and low diversity: up to 110 specimens and 12 genera per slide, in contrast to Silurian ones that are more frequent and more diverse $->3000$ specimens and 16 genera per slide (diversity at the species level is also higher). Throughout the Ordovician part of the succession, typical Ordovician genera occur, such as Acanthodiacrodium, Ordovicidium, Orthosphaeridium and large Baltisphaeridium, together with isolated occurrences of typical Silurian genera, especially in the upper part of the Hirnantian (e.g., Diexallophasis). The Silurian assemblages are typified by high frequency of prasinophytes followed by typical Silurian acritarchs: Tylotopalla, Ammonidium, Domasia and Oppilatala. The palynological material from Poland is compared with material known from other localities: the Rapla and Valga boreholes (Estonia) and Anticosti Island (Canada), as well as others placed in different palaeocontinents and different bathymetric zones. Palynological assemblages obtained from Polish material confirm that bathymetry played the key role in taxonomic diversification of the microphytoplankton assemblage. This supports the existing models of distribution: dominance of prasinophytes (leiospheres) and cryptospores is characteristic for shallow-water environments. In deeper water, dominance of acanthomorphs is observed. In the deepest-water zones - mixed assemblages occur. For the Holy Cross Mountains, microphytoplankton frequency is compared with a TOC curve in the same interval.

Key words: Poland, Ordovician/Silurian boundary, palynology, acritarch frequency, bathymetry, climate.

\section{INTRODUCTION}

One of the longest, most significant and sustained intervals of biotic diversification in the history of marine life on Earth occurred in the Ordovician Period (Miller and Mao, 1995; Miller, 1997; Servais et al., 2008). Evolutionary diversification during the Early and Middle Ordovician was interrupted in the latest Ordovician (Hirnantian) by one of most intense mass extinction events of the Paleozoic Era. The end-Ordovician mass extinction is associated with climate change and regression accompanied by a major glaciation on the Gondwana supercontinent (Beuf et al., 1971; Brenchley, 1988; Finney et al., 1997). Raup and Sepkoski (1982) calculated that $\sim 22 \%$ of all marine families, $40 \%$ of marine genera (Sepkoski, 1996) and $85 \%$ of marine species (Jablonski, 1991) became extinct in the Late Ordovician.

\footnotetext{
* Corresponding author, e-mail: teresa.podhalanska@pgi.gov.pl
} Received: October 25, 2019; accepted: December 13, 2019; first published online: March 4, 2020
During the Early Silurian, the global ecosystem gradually recovered from this mass extinction - during it, no major taxonomic groups disappeared - and biodiversity rose again during warmer palaeoclimatic conditions (Armstrong, 1996, 2007; Berry et al., 1996; Armstrong and Harper, 2014). The characteristics of microphytoplankton response to the Hirnantian biotic crisis and following the early Silurian recovery are still incompletely constrained. A general reduction in both diversity and frequency of acritarchs at the genera and species level during the Late Ordovician has been recorded in various localities worldwide (Paris et al., 2000; Servais et al., 2008; Stempień-Sałek, 2011). The Early Silurian (Llandovery) is characterized by a resurgence of amount and turnover: appearance of new taxa and expansion of taxa that appeared right at the end of the Ordovician (those of Silurian "affinity" sensu Le Hérissé in Paris et al., 2007:103).

The global and regional patterns of acritarch recovery after the Hirnantian mass extinction are relatively unknown, mainly due to the scarcity of detailed studies. A major problem affecting the analysis of acritarch distribution within stratal successions that span the Ordovician-Silurian boundary is the lithofacies control on the preservation of organic-walled microfossils (for example in Saudi Arabia - Le Hérissé, 2000; and Bohemia - Dufka and Fatka, 1993). 


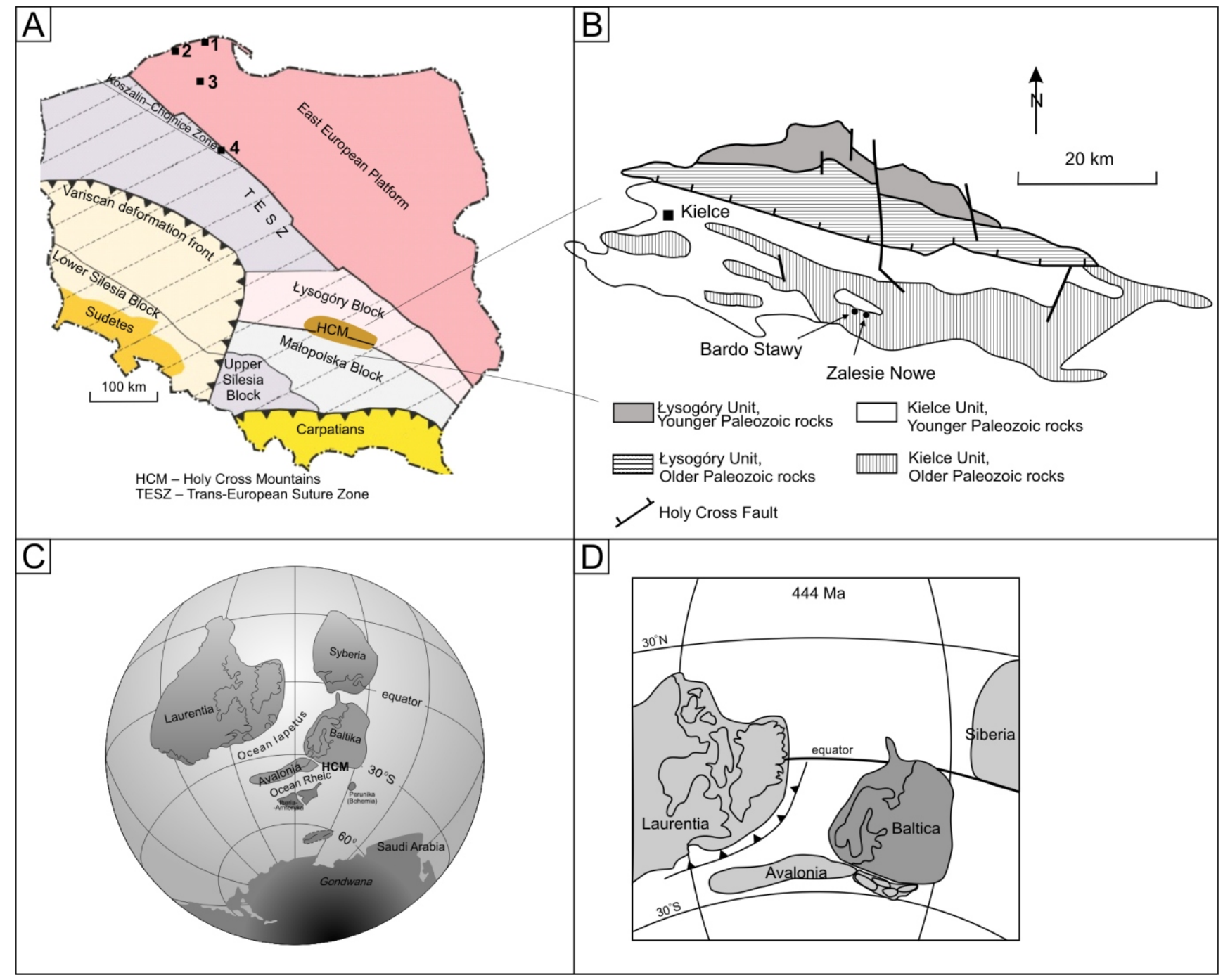

Fig. 1A - areas of investigation (a map after geoportal.pgi.gov.pl, supplemented): East European Platform, Baltic Depression: 1 Białogóra 1 borehole, 2 - Łeba 8 borehole, 3 - Kościerzyna IG 1 borehole and Koszalin-Chojnice Zone; 4 - Toruń 1 borehole; B Bardo Stawy and Zalesie Nowe sections in the Holy Cross Mountains, Kielce Region; palaeogeography: C - Late Ordovician (after Torsvik and Cocks, 2005, supplemented), D - Early Silurian (after Nawrocki et al., 2007, supplemented)

In the present study, acritarch diversity data were collected from Ordovician-Silurian transitional strata at three different main localities in Poland: Holy Cross Mts. (Małopolska Block), East European Platform: Pomerania (Baltica), and Western Pomerania (Koszalin-Chojnice Zone). All localities are shown in Figure 1.

The most complete record of microphytoplankton from O/S boundary strata comes from the Holy Cross Mts. (Małopolska Block) and poses a benchmark for assemblages from other Polish successions. In the the Bardo Stawy succession, strata demonstrate the response of acritarchs to palaeoenvironmental change through the latest Ordovician and earliest Silurian. The far-field effect of glaciation in Gondwana is evident in the latest Ordovician (Hirnantian), equated with a global climate cooling that may have been a major causal effect of mass extinction, including planktonic organisms such as graptolites, and impacting on reduced diversity within acritarch assemblages: this interval is also associated with the widespread appearance of the $\mathrm{cool} /$ ventilated-water Hirnantia fauna at lower latitudes (Rong et al., 2002). The global warming in the latest Ordovician and earliest Silurian is associated likely with oceanographic change (temperature, thermohaline circulation, etc.) that facilitated the recovery as an increase in frequency (numerical abundance and biodiversity) of acritarchs. Lithofacies studies confirm the regressive nature of Upper Ordovician deposits related to the growing ice sheet of the Southern Hemisphere. The maximum climate cooling and sea level regression took place during the early Hirnantian - extraordinarius graptolite Biozone using the British graptolite biozonation (Armstrong, 2007; Page et al., 2007). An equivalent of this zone in Poland is the Mucrionaspis mucronata trilobite Biozone due to the lack of graptolites (Kielan, 1956, 1959). In the uppermost Hirnantian (persculptus graptolite Biozone), represented by the deglaciation interval, the first signs of warming and eustatic change occurred with the deposition of beige claystones and shales containing silt- to sand-sized quartz grains, preceding the facies change to dark "graptolitic shales". Such a lithological succession indicates gradual stagnation and progressive oxygen deficiency of the depositional environment related to a deepening of the sea during the post-glacial sea level rise (Masiak et al., 2003). The results presented here are a further contribution to the understanding of the timing and causal mechanisms of early Silurian acritarch recovery after the Hirnantian mass extinction and its possible connection with the associated palaeoclimate and palaeoenvironmental change. 


\section{GEOLOGICAL SETTING}

The palynological material analysed in this paper comes from both outcrops in central Poland and boreholes in northern Poland (Fig. 1A, B).

The study sections are located in three distinct palaeogeographic regions (sensu Torsvik and Cocks, 2005; Nawrocki and Poprawa, 2006; Nawrocki et al., 2007) - the Małopolska Block (Kielce Region), Baltica (Baltic depression) and Koszalin-Chojnice Zone (Fig. 1A, B). All localities, the Małopolska Block, Baltica and Koszalin-Chojnice Zone, occupied different palaeogeographic positions during Late Ordovician Hirnantian time, although the palaeolatitudes $\left(\sim 30^{\circ} \mathrm{S}\right)$ were similar (Lewandowski, 1993; Bednarczyk, 1999; Cocks, 2000; Cocks and Torsvik, 2005; Torsvik and Cocks, 2005). They were located in the same basin around western Baltica. The palaeogeographic positions are shown in Figure 1C, D.

MAŁOPOLSKA BLOCK

In the Early Ordovician the Małopolska Block was placed at $\sim 60^{\circ} \mathrm{S}$ latitude (Lewandowski, 1993) and through the Ordovician it moved northward reaching $\sim 30^{\circ} \mathrm{S}$ latitude in the Late Ordovician (Cocks and Torsvik, 2002; Torsvik and Cocks, 2005; Nawrocki et al., 2007). The geotectonic provenance of the Małopolska Block is still unclear, but some authors consider it as a Gondwana-derived terrain (Belka et al., 2000), others as a proximal terrain that detached from Baltica before the Ordovician (Dadlez et al., 1994; Narkiewicz, 2002). Southern part (Kielce Region) of the Holy Cross Mts. is considered a northern part of the Małopolska Block.

Ordovician/Silurian boundary deposits described in this paper come from the Bardo Stawy and Zalesie Nowe sections that are located in the Bardo Syncline (Fig. 1B). The Bardo Syncline is a small tectonic unit, $\sim 16 \mathrm{~km}$ long and $2-5 \mathrm{~km}$ wide, oriented in a NW-SE direction. This Variscan structure is composed of Ordovician and Silurian deposits truncated and conformably overlain by Devonian sediments (Fig. 1B). These Paleozoic deposits are blanketed largely by a thick Quaternary cover. The outline of the Syncline is underlined by diabase intrusions that follow the boundary between Silurian graptolitic shales and greywackes.

The Ordovician/Silurian boundary interval of the Bardo Stawy section comprises a complete succession of deposits from the uppermost mucronata, ?persculptus, ascensus-acuminatus and vesiculosus biozones (Masiak et al., 2003 and Fig. 2) and exhibits a conformable and gradual transition from sandy through silty to clayey deposits, which is accompanied by a gradual change of colour of the rock from light to dark. This uppermost Ordovician-lowermost Silurian succession indicates a depositional environment that became oxygen-poor during the post-glacial sea level rise.

Deposits in the Zalesie Nowe section are divided into local formations (Bednarczyk, 1971, 1981). The topmost part of the Zalesie Formation (Fig. 3) is composed of marls and dark red and grey-greenish marly shales that grade consequently into dark grey shales interbeded by lydites - called the Bardo Beds. The lower stratigraphic unit (uppermost Zalesie Fm.) - the so called Dalmanitina Beds - is well-documented by the trilobite Mucronaspis mucronata as latest Ashgill (Kielan, 1956), pointing to a Hirnantian age. The latest investigation of graptolite fauna (Kremer, 2001) indicates a Late Ordovician (Ashgill) Early Silurian age for the Bardo Beds at Zalesie Nowe.
A full lithological description of both sections (Bardo Stawy and Zalesie Nowe) is presented in Masiak et al. (2003) and Mustafa et al. (2015). The lithology and lithostratigraphy of the Lower Silurian deposits in the Bardo Stawy section was presented by Trela and Salwa (2007).

\section{BALTICA (BALTIC DEPRESSION)}

The Baltic Depression was developed in the southwestern part of the Baltica palaeocontinent (nowadays East European Platform) and was placed $\sim 30^{\circ} \mathrm{S}$ latitude during the Late Ordovician (Cocks and Torsvik, 2002; Torsvik et al., 2002; Torsvik and Cocks, 2005; Nawrocki et al., 2007). Delabroye et al. (2011a) call this area the Livonian Basin after Kaljo et al. (2008; Livonian tongue of the central Baltoscandian Facies Belt). Baltica was geographically located at low southerly latitudes during the Early Ordovician and drifted slowly northward. In Late Ordovician/Early Silurian times, the East European Platform occupied subtropical and equatorial southern latitudes (Fig. 2).

The uppermost Ordovician and lowermost Silurian deposits in the Baltic Depression have been identified in numerous boreholes. In this region, all facies belts of the Baltic Basin are recognized - from the basinal facies in the west, through the slope, deep- and shallow-neritic, to the onshore facies in the east (see Podhalańska, 2009).

The material investigated in this study comes from boreholes situated in the Łeba area and corresponds to a deep neritic part of the sea, a southward extension of the Scanian confacies belt (see Podhalańska, 2009). The western border of the Baltic Depression is the TESZ and Koszalin-Chojnice Zone, which contain deep-water lithofacies.

The uppermost Ordovician strata in the Baltic Depression are generally developed as shaly-calcareous, calcareous and calcareous-dolomitic, and shaly glauconitic deposits, though the lithofacies differ between the western and eastern parts. The lithological descriptions of some borehole sections can be found, e.g., in Tomczyk (1962), Tomczykowa (1964), BednarCzyk (1968, 1971, 1996a, 1998, 1999), Podhalańska (1980, 1999, 2003a, b, 2009), Przybyłowicz (1980), Bednarczyk et al. (1996), Modliński and Szymański (1997, 2008), Podhalańska and Modliński (2006).

Sedimentation across the Ordovician/Silurian boundary in the bottom depressions took place probably without a break and the facies changes were gradual. Non-deposition, submarine erosion and minor hiatuses took place on bottom elevations and the transgressive unconformity surface (e.g. in the Kościerzyna IG 1 section) separates the partly eroded Hirnantian dark grey marls and sandstones containing the Hirnantia fauna from the laminated deeper marine Rhuddanian shales with graptolites of the acuminatus Biozone.

In the boundary beds, abundant marine faunas are well-documented: graptolites (Podhalańska and Modliński, 2006; Podhalańska, 2009), trilobites and inarticulate brachiopods (Bednarczyk, 1968; Modliński, 1988), ostracods, conodonts (Nehring, 1969; Bednarczyk, 1998), and the Hirnantia fauna (Podhalańska, 1980, 1999, 2003b, 2009).

The total thickness of the uppermost Ordovician (Ashgill Series) in the Baltic Depression varies from 3.5 to $70 \mathrm{~m}$ (Modliński and Szymański, 1997). A palaeothickness map of the Middle-Upper Ordovician deposits is shown in Modliński et al. (1999) and Modliński (2010). The total thickness of the lowermost Silurian (Llandovery) varies from 20 to 70 m (Modliński et al., 2006), and increases from east to west. 


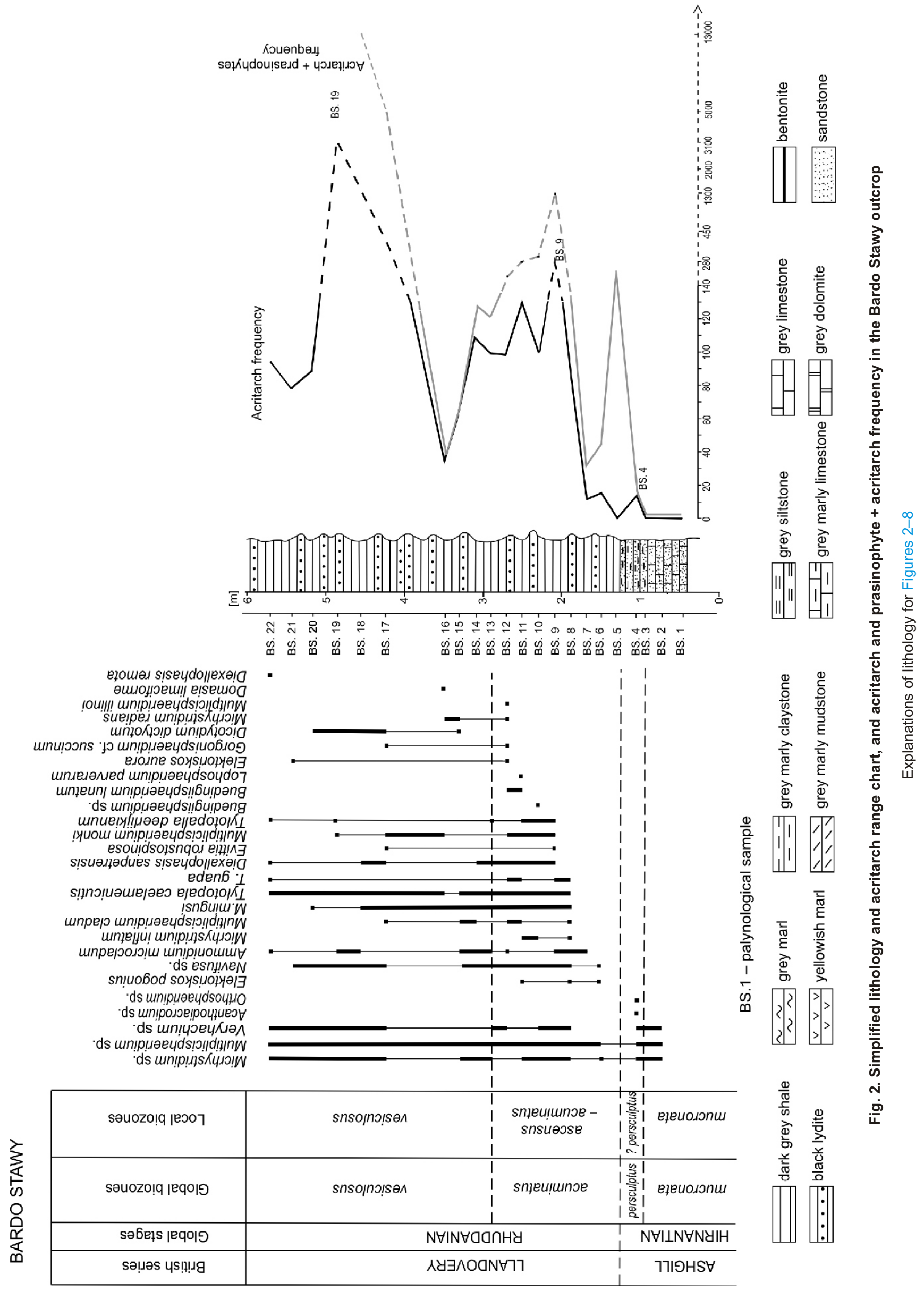




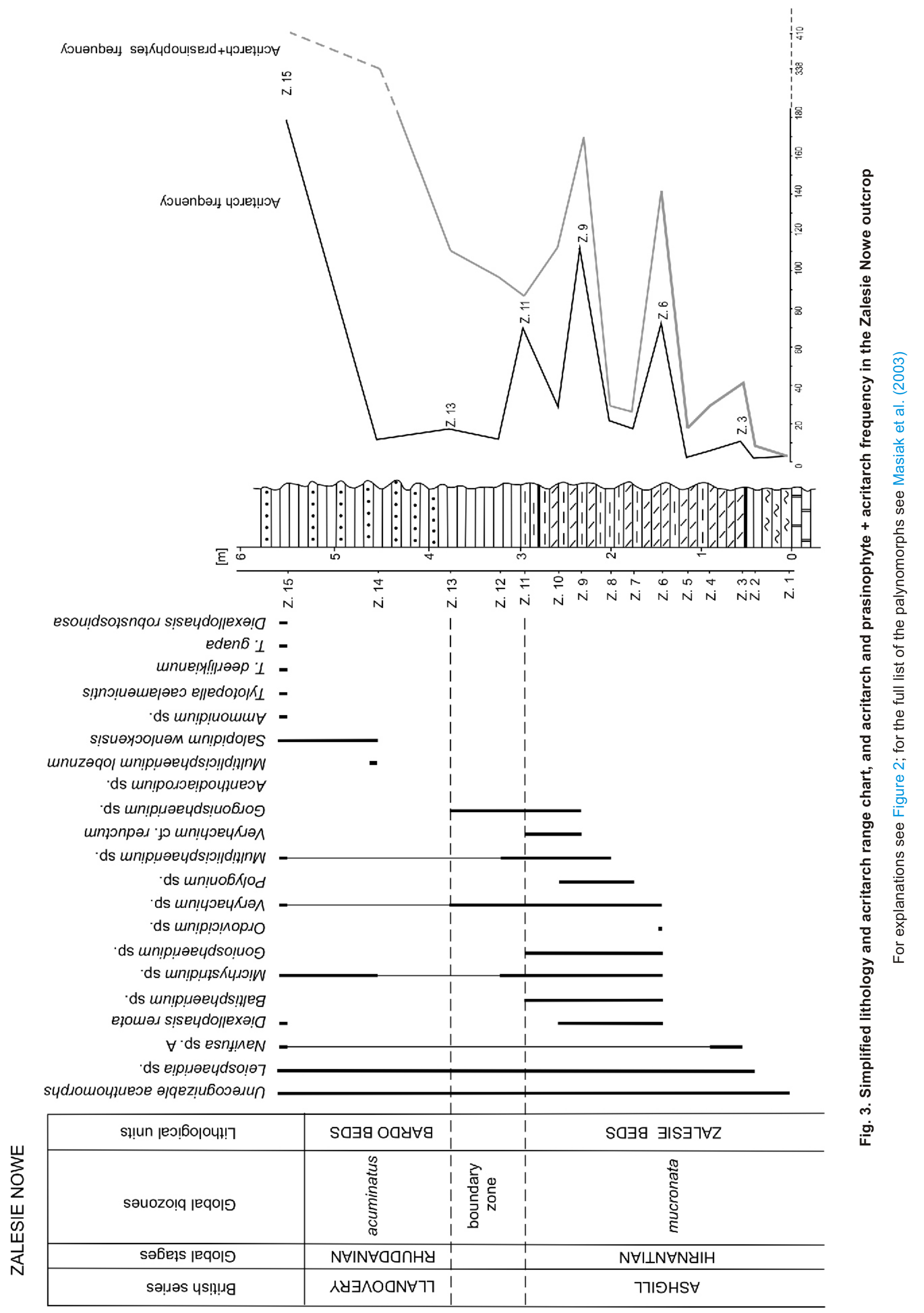




\section{KOSZALIN-CHOJNICE ZONE}

The Koszalin-Chojnice Zone (Fig. 1A) is placed on an epi-Caledonian platform (Karnkowski, 2008: fig. 2 therein), on the border of the SW margin of the East European Platform and Avalonia (e.g., Belka et al., 2000; Poprawa, 2006; Podhalańska and Modliński, 2006). The Koszalin-Chojnice Zone is regarded as a Caledonian front of collision deformation (Żelaźniewicz et al., 2011: fig. 5).

The crystalline basement of the Ordovician strata in the Koszalin-Chojnice Zone is supposed to be an Early Paleozoic terrane derived from Gondwana, described as Eastern Avalonia (Tait et al., 1997; Pharaoh, 1999; Jaworowski, 2000; Wrona et al., 2001; Samuelsson et al., 2002). Early Paleozoic deposits of this zone contain biotic assemblages of both Baltic and Avalonian origin (Podhalańska and Modliński, 2006 Torsvik and Cocks, 2013).

During the movement of Avalonia towards Baltica, in Ordovician and Silurian times, the Koszalin-Chojnice Zone was the proximal part, whereas the Baltic Basin was the distal part of the same basin. The distance between them was relatively close but they were immediately adjacent (Krzemiński and Poprawa, 2006).

The Paleozoic sedimentary cover of the Koszalin-Chojnice Zone includes Ordovician deposits identified in many boreholes that were drilled mainly in the 1960s and 1970s (Tomczyk 1968; Modliński, 1968, 1978, 1987; Bednarczyk, 1974; Dadlez. 1978, 1982a, b, 1993, 2000).

The Middle-Upper Ordovician and Silurian deposits form the Older Paleozoic sequence. This sequence, composed mainly of shales (dark grey and grey clayey-muddy sediments with scarce sandy, dolomitic and sideritic intercalations - e.g. Krzemiński and Poprawa, 2006), is intensely folded and unconformably overlain by the younger Paleozoic sequence.

The strata above the Ordovician locally attain $4000 \mathrm{~m}$ in thickness. The Upper Ordovician in the Koszalin-Chojnice Zone is documented (Podhalańska and Modliński, 2006) by graptolites only for the Sandbian (Caradocian). Other groups of fossils, such chitinozoans, prasinophytes and various trace fossils, also fragments of brachiopods and trilobites, occur sporadically (Bednarczyk, 1974; Wrona et al., 2001; Podhalańska, 2007). Palynological data based on acritarchs indicates a Llanvirn-Caradoc age of the Ordovician deposits of the Pomeranian Caledonides (Szczepanik, 2000).

The latest stratigraphic division of the uppermost Ordovician is based on a correlation with the Polskie Łaki PIG 1 borehole and other boreholes. The overlying deposits are Sandbian in age, and are strongly deformed and faulted. A tentative stratigraphic subdivision is based on lithofacies studies (Podhalańska and Modliński, 2006).

Llandovery deposits are represented by deep-marine siliciclastic sediments most frequently containing sedimentary structures related to sea current activity (Teller and Korejwo 1968; Teller, 1974; Podhalańska and Modliński, 2006). The strata documented in the Torun 1 borehole are Silurian in age (lower Llandovery, Rhuddanian; Dadlez, 1982b; Tomczyk 1987). Currently, it is not possible to define the detailed stratigraphy due to poor preservation of the rock and tectonic deformation. The original thickness of the strongly folded Llandovery deposits (Lutom 1 and Torun 1 sections) is $>400 \mathrm{~m}$ (Poprawa, 2006).

The macrofaunal assemblage found in the Llandovery deposits was dominated by graptolites and rare inarticulate brachiopods. The frequency of graptolites is low. Among microfossils, the presence of acritarchs, prasinophytes and chitinozoans was documented by Teller (1974), Jachowicz (2000), Wrona et al. (2001) and Podhalańska and Modliński (2006). Numerous tectonically deformed biserial graptolites were found in black shale in the Torun 1 section at a depth of 5298.0 m (Podhalańska and Modliński, 2006). They indicate the presence of Rhuddanian deposits, which succeed the strongly folded Upper Ordovician rocks.

\section{MATERIAL AND METHODS}

\section{MATERIAL}

The palynological investigation presented in this paper includes data from 73 samples collected and studied over the past few years - palynological data, especially palynomorph frequency, were obtained as an additional result of studies on stratigraphy by the Institute of Geological Sciences PAS in Warsaw. Thus, only acritarchs were counted in some cases (Zalesie Nowe and Kościerzyna IG 1), but generally acritarchs and prasinophytes were counted for their frequency.

Thirty-seven samples from the Holy Cross Mountains (Fig. 1B) yield both well-preserved material - yellow to brown acritarchs and yellow prasinophytes in the Bardo Stawy samples - and less well-preserved dark brown to black palynomorphs in the Zalesie Nowe samples. Detailed description of samples is published in Masiak et al. (2003) and shown in Figures 2 and 3 in this paper.

The material from the East European Platform (Baltica palaeocontient, Baltic Depression) consists of samples from three boreholes: Białogóra 1, Kościerzyna IG 1 and Łeba 8 (Fig. 1A). Thirty-two samples from dark grey shales were taken, which span a stratigraphic interval equivalent to the uppermost Hirnantia beds of the mucronata trilobite Biozone, the ascensus graptolite Biozone (Early Silurian, Rhuddanian), and the lowermost part of the succeeding acuminatus graptolite Biozone (Silurian).

The material studied for palynology in the Koszalin-Chojnice Zone comprises four samples from the Torun 1 borehole (Fig. 1A). All samples are from dark grey shale. This interval probably spans the uppermost part of the Hirnantia beds (mucronata trilobite Biozone) to the Llandovery (Rhuddanian) undivided.

The material from the East European Platform and the Koszalin-Chojnice Zone is poorly preserved, mostly incomplete and dark brown to black in colour.

Preservation in some samples is too poor to distinguish the acanthomorphic acritarchs with a short process from prasinophyte algae. In other samples, however, the sphaeromorphs are sufficiently well-preserved - especially the existence of thin-walled forms - to indicate that the lack of acritarchs is probably primary and not the result of preservation. Obviously, it cannot be excluded that some specimens were destroyed during post-sedimentation processes.

There are few samples from the Torun 1 borehole because of long non-cored intervals. Generally, all palaeontological data from boreholes of the Koszalin-Chojnice Zone are scarce and poor, so the authors decided to publish even these modest data.

The position of individual samples taken from boreholes is measured directly from the core depth, not from well logs. All slides are housed at the Department of Stratigraphy and Palaeogeography, Institute of Geological Sciences, PAS (ING PAN) Warsaw, Poland. 


\section{PALYNOLOGICAL METHODS}

All samples were subjected to a standard palynological laboratory treatment (Wood et al., 1996). The samples were used for quantitative analysis of assemblage similarity. In this analysis, the organic residues obtained after complete dissolution of $5 \mathrm{~g}$ of rock were supplemented to a volume of $4 \mathrm{ml}$ with methyl alcohol. From each sample, three slides were made; and for each slide, $0.5 \mathrm{ml}$ of well-mixed solution was analysed for palynomorphs. For each sample level, the arithmetic mean was calculated from three slides. The same method was used in Masiak et al. (2003).

\section{RESULTS}

\section{MAŁOPOLSKA BLOCK}

Palynological data from the sections and boreholes are different. The richest and most diverse assemblages are from the Early Silurian of the Bardo Stawy section (Fig. 2). This section is the best-documented according to palynological and graptolitic assemblages (Masiak et al., 2003) and in our investigation is treated as a benchmark for comparison with other sections.

The latest Ordovician palynological assemblage in the Bardo Stawy section includes only long-ranging acritarchs, mainly of simple morphology. The acritarch frequency is poor to moderate (samples BS. 1 to BS. 4) - from 0 to 20 specimens per sample. The Ordovician/Silurian boundary in the Bardo Stawy section (BS. 5) is marked by a considerable decrease of acritach frequency - the sample is barren. The frequency and diversity increase in the lower part of the ascensus-acuminatus graptolite Biozone of the Early Silurian (BS. 6-BS. 13): a significant peak in both diversity and frequency is observed in sample BS. 9 (up to 280 specimens per slide). In the Bardo Stawy section, the maximum acritarch frequency is attained in the lower part of the vesiculosus graptolite Biozone, although the genera and species diversity do not change (sample BS. 19). This change in acritarch assemblages does not appear to be related to lithology. For detailed descriptions of palynological assemblages see Masiak et al. (2003). Apart from acritarchs, there are many sphaeromorphs, such as Leiosphaeridia spp. regarded as prasinophytes (Le Hérissé, 1989), as well as prasinophytes from two genera: Cymatiosphaera and Pterospermella sp. (samples BS. 17-BS. 19).

The number of prasinophyte specimens was counted in samples BS. 1 to BS. 18. Samples BS. 1 to BS. 3 contain no specimens. From BS. 4 to BS. 5, the number of specimens increases to 260 specimens per slide. The next peak in the frequency is noted in sample BS. 9 (1300 specimens per slide) and then a decreasing trend is observed. A minimum is noted in BS. 16 (no specimens). Starting from sample BS. 17, the number of specimens rapidly increases and the maximum frequency is noted in sample BS. $18-13,000$ specimens.

In the Zalesie Nowe section (Fig. 3), the trend in microphytoplankton diversification is similar, but the overall diversity is always lower than in the Bardo Stawy section, which could be connected with differences in lithology. The main difference here is the poorly defined O/S boundary because of lack of index graptolite.

A distinct drop in acritarch and prasinophyte frequency is evident in the O/S boundary zone in the Zalesie Nowe section within the interval of clayey shales (Z12-Z13). This change is similar to the decrease in frequency in the Bardo Stawy section (?persculptus - lowermost part of the ascensus-acuminatus biozones). This boundary zone involves most probably the ?persculptus graptolite Biozone and the lowermost part of the ascensus-acuminatus Biozone and is defined by the occurrence of a distinct drop in acritarch frequency, similar to that of the Bardo Stawy profile. Regarding the frequency and diversity of microphytoplankton, the peak observed in sample Z. 15 may be at the same level as that of sample BS. 9 in the Bardo Stawy section. Detailed description of the Zalesie Nowe section is published in Masiak et al. (2003) and Mustafa et al. (2015).

Microphytoplankton from the described sections of the $\mathrm{HCM}$ is generally well preserved, yellow to pale brown in colour.

BALTICA (BALTIC DEPRESSION)

Microphytoplankton assemblages of the Białogóra 1, Kościerzyna IG 1 and Łeba 8 boreholes are generally poor and poorly preserved, dark grey to black in colour, and surficially corroded (in contrast to those from the southern part of the Holy Cross Mts., which are much clearer), which is caused by different thermal maturity.

Range charts of the most important genera and species are shown in Figures 4-6.

\section{BIAŁOGÓRA 1 BOREHOLE.} ure 4.

Detailed data from the Białogóra 1 borehole is shown in Fig-

The lowermost palynological sample from the uppermost Ordovician (Hirnantia beds) in the Białogóra 1 borehole (sample B1.8) is barren. The first change in diversity and frequency of microphytoplankton occurs in the upper part of the Hirnantian in sample B1.7. The assemblage is poorly diverse and comprises mainly long-ranging taxa, such as Micrhystridium sp., Multiplicispaeridium sp., Veryhachium sp. and importantly the Upper Ordovician index taxa of Baltisphaeridium sp., Ordovicidium sp. and Orthosphaeridium sp. The sample contains prasinophytes (Leiosphaeridia spp.) comparable in number to the acritarchs.

The slide for sample B1.6 comprises 46 specimens of acritarchs recognizable mainly at the generic level: Baltisphaeridium sp. (probably redeposited), Diexallophasis $\mathrm{sp}$.. Micrhystridium sp., Multiplicisphaeridum sp. and Oppilatala $\mathrm{sp}$. This sample contains a very large number of prasinophytes (Leiosphaeridia spp.) up to 200 specimens per slide.

The frequency in the next sample (B1.5) is decreasing with only nine leiosphaeres (Prasinphyceae) and two unrecognizable acanthomorphs. Sample B1.4 is more abundant - it contains 33 specimens per slide. Some new species appear: Tylotopalla caelamenicutis, T. deerlijkianum, T. guapa and ?Oppilatala sp. The sample contains a huge number of prasinophytes (Leiosphaeridia spp.) - 880 specimens per slide.

In following two samples - B1.3 and B1.2 that represent the upper part of the ascensus Biozone, the abundance of acritarchs goes down to $<20$ specimens per slide (B1.3 - 17 specimens, B1.2-10), but the number of prasinophytes is decreasing to 230 specimens per slide.

The frequency and diversification of acritarchs in the sample from the lowermost part of the acuminatus Biozone (B1.1) increases to 43 specimens per slide, whilst the frequency of prasinophytes is still prominent $->500$ specimens.

\section{KOŚCIERZYNA IG 1 BOREHOLE}

Detailed data from the Kościerzyna IG 1 borehole is shown in Figure 5. The palynological samples from the uppermost Ordovician (Hirnantia beds) in this borehole (samples K21-K15) 


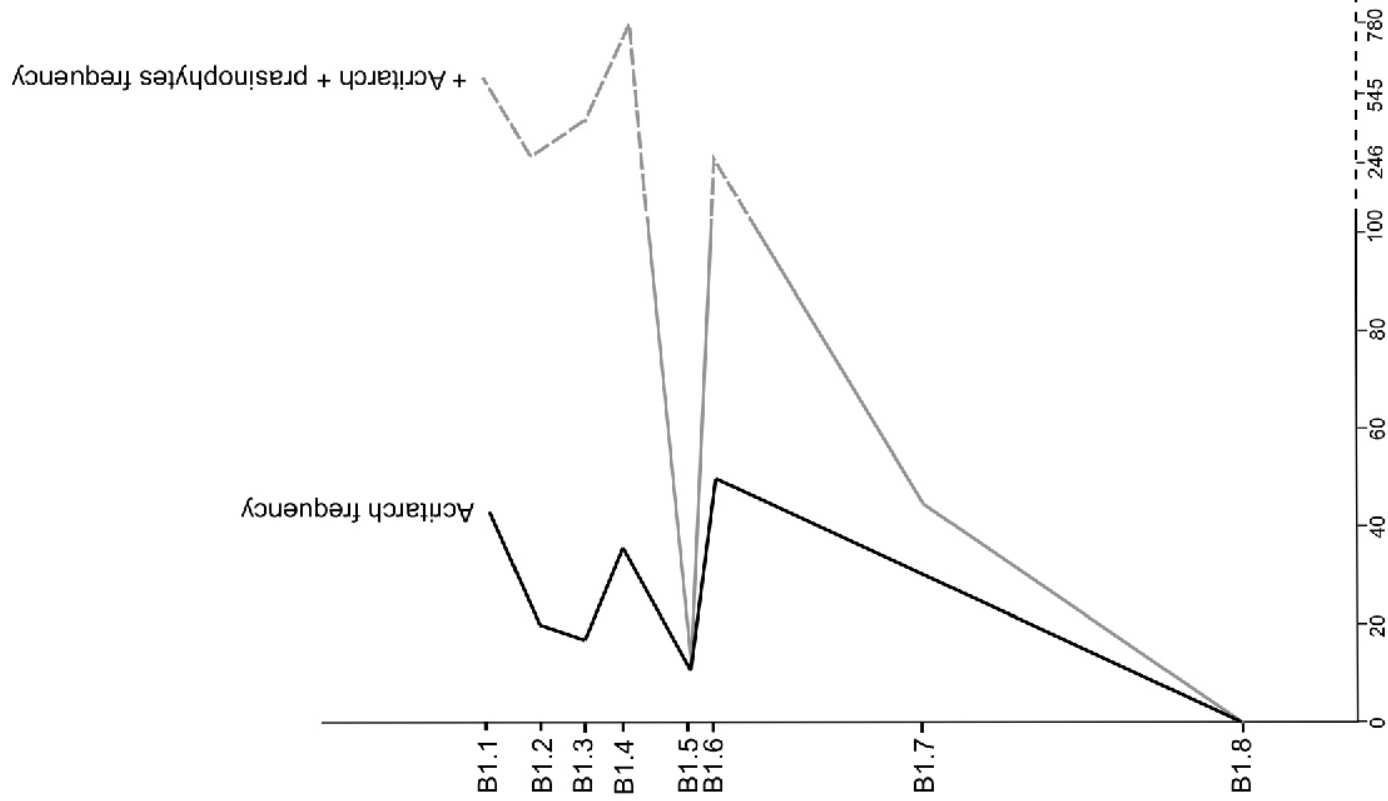

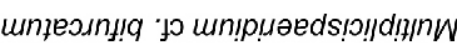

\begin{tabular}{|c|c|c|c|c|c|c|}
\hline səuozo!̣ ן ןอ०ך & 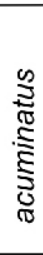 & 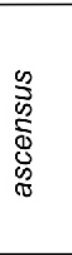 & 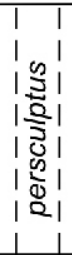 & 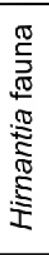 & 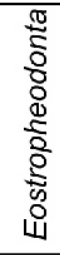 & 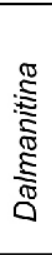 \\
\hline səuozo!̣ |eqo| & \multicolumn{2}{|c|}{ snjeu!usnoe } & I & \multicolumn{3}{|c|}{ efeuodonu } \\
\hline sa6els jeqol⿹ & \multicolumn{2}{|c|}{ N $\forall I N \forall O O \cap H Y$} & $T$ & \multicolumn{3}{|c|}{ N $\forall I \perp N \forall N Y y I H$} \\
\hline sə!!əs पs!!!ఎด & \multicolumn{2}{|c|}{ 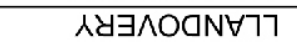 } & & \multicolumn{3}{|c|}{ ᄀᄀ। } \\
\hline
\end{tabular}




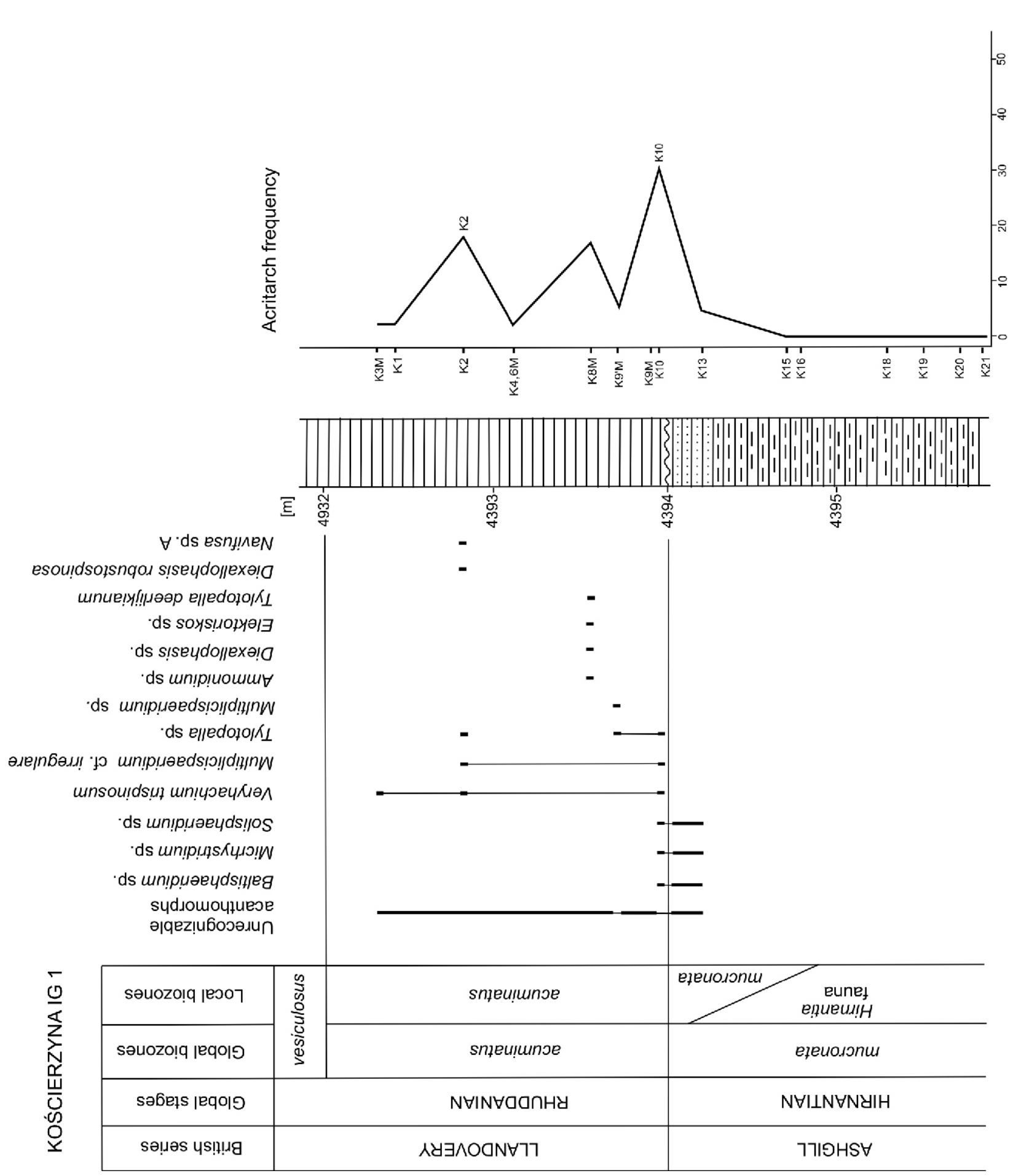

are barren. The first change in diversity and frequency of microphytoplankton occurs in the upper Hirnantian in sample $\mathrm{K} 13$. The assemblage is poorly diversified and comprises mainly long-ranging taxa, such as Micrhystridium sp. and Solisphaeridium sp., and the Upper Ordovician index taxon Baltisphaeridium sp.

The slide for sample K10, which is the first Silurian sample, comprises 30 specimens of acritarchs recognizable mainly at the generic level: Baltisphaeridium sp. (probably redeposited), Micrhystridium sp., Multiplicisphaeridum cf. irregulare, Veryhachium trispinosum, Tylotopalla sp. and Solisphaeridium sp.

The frequency in the next sample (K9'M) is decreasing, only a few leiospheres and two acanthomorphs occur (Multiplicisphaeridium sp. and Tylotopalla sp.). The assemblages in sam- ple K8M are more abundant - comprising 17 specimens per slide. Some new species appear: Ammonidium sp., Diexallophasis sp., Elektoriskos sp. and Tylotopalla deerlijkianum.

In the following sample - K4,6M, the abundance of microphytoplankton decreases. The frequency in the next sample K2 increases to 18 specimens per slide. The assemblage is poorly diversified and contains only long-ranging taxa: Veryhachium trispinosum, Multiplicisphaeridium sp. and Tylotopalla sp.

In the two last samples $\mathrm{K} 1$ and $\mathrm{K} 3 \mathrm{M}$, the frequency dramatically decreases ( 2 specimens per slide). In $\mathrm{K} 1$, two new taxa appear: Diexallophasis robustospinosa and Navifusa sp.

Prasinophytes were not counted (see explanations in chapter Material and methods). 


\section{ŁEBA 8}
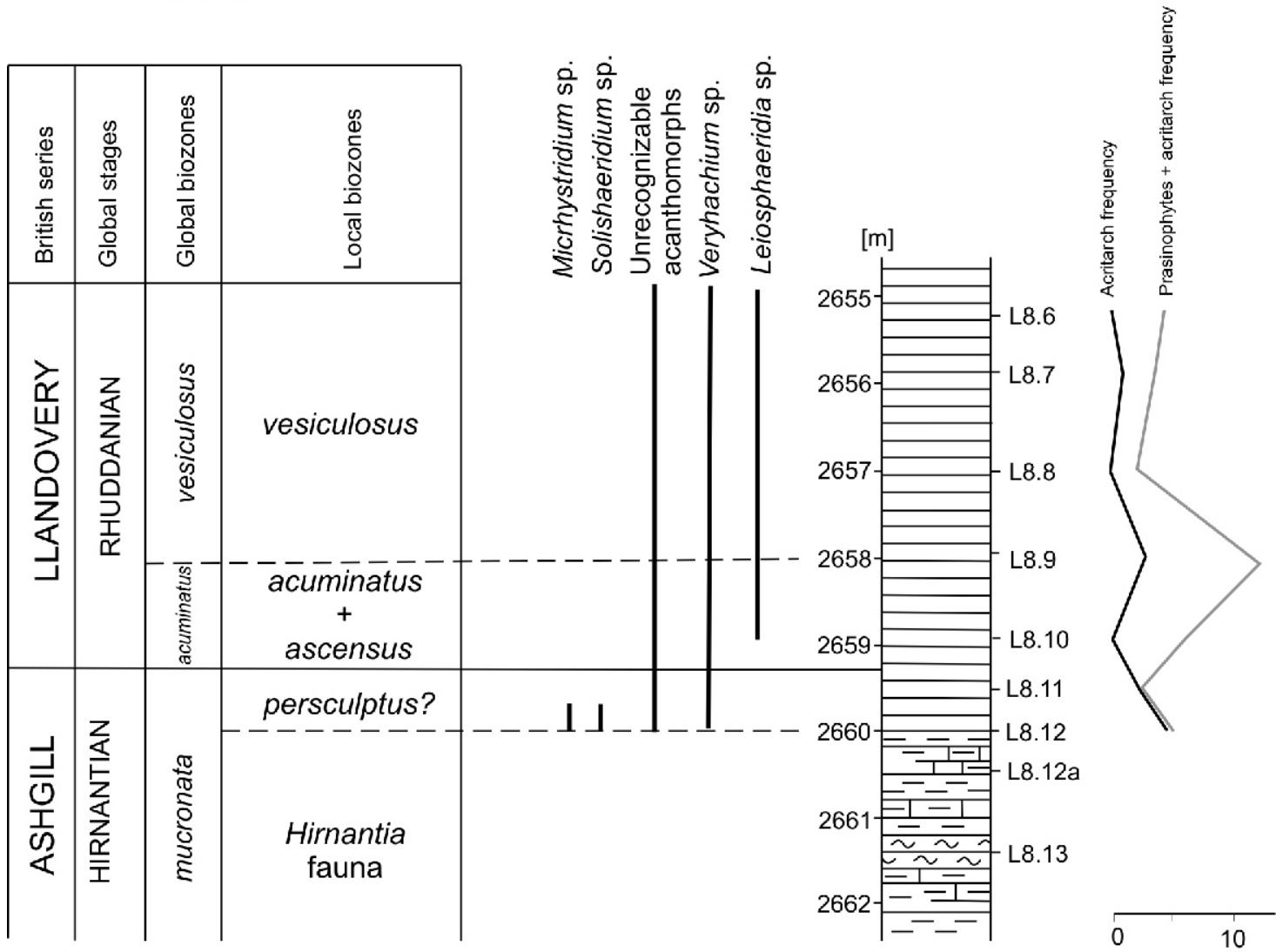

Fig. 6. Simplified lithology and acritarch range chart, and acritarch and prasinophyte + acritarch frequency in the Łeba 8 borehole

For explanations see Figure 2

ŁEBA 8 BOREHOLE

Detailed data from the Łeba 8 borehole is shown in Figure 6.

Microphytoplankton is very poorly preserved (dark brown and black) in the borehole. Only three recogniszable taxa occur. Most acanthomorphs are indeterminate even to the generic level, and there are also some Leiosphaeridia. The most productive sample in terms of acritarch taxa recognizability is L8.12 (persculptus? graptolite Biozone), while sample L8.9 (probably the uppermost part of the ascensus + acuminatus graptolite Biozone) is richer in both acritarchs and prasinophytes - with 12 specimens per slide.

\section{KOSZALIN-CHOJNICE ZONE - TORUŃ 1 BOREHOLE}

Detailed data from the Torun 1 borehole is shown in Figure 7.

The palynological assemblage in the samples from the Uppermost Ordovician (Hirnantia beds) of the Torun 1 borehole (samples T.1.5 and T.1.4) is diverse and moderately abundant (up to 18 specimens per slide). It comprises mainly long-ranging taxa. Almost all the above-listed, except Deunffia sp. and Pterospermella sp., occur in sample T.1.3 (lowermost Silurian). The abundance dramatically decreases through the investigated interval to three specimens per slide in T.1.3, and to two specimens in sample T.1.2.

\section{COMPARISON OF DATA FROM POLAND WITH OTHER REGIONS}

A major problem affecting the analysis of acritarch distribution across the Ordovician-Silurian boundary is the lithofacies control on preservation of organic-walled microfossils. Palynomorphs, such as acritrachs and prasinopytes, prefer specific, characteristic facies of environments with prevalence of fine-clastic sedimentation. Based on this fact, in the other world localities of the O/S boundary, the possibility of following the trend of frequency and diversity of acritarch assemblages is straitened because of lack of relevant facies and continuity of deposits (Fig. 8).

The Bardo Stawy, Zalesie Nowe, Białogóra and Łeba sections are unique because of sedimentary continuity and palynological yields across the O/S boundary, as well as good independent stratigraphic control provided by graptolites.

In the following section, we compare the present results with previously published similar studies, as conducted in a different palaeogeographic position, regarding also the bathymetry and dependence of acritarchs and prasinophytes on sea depth (Al-Ameri, 1983). 


\section{TORUŃ 1}

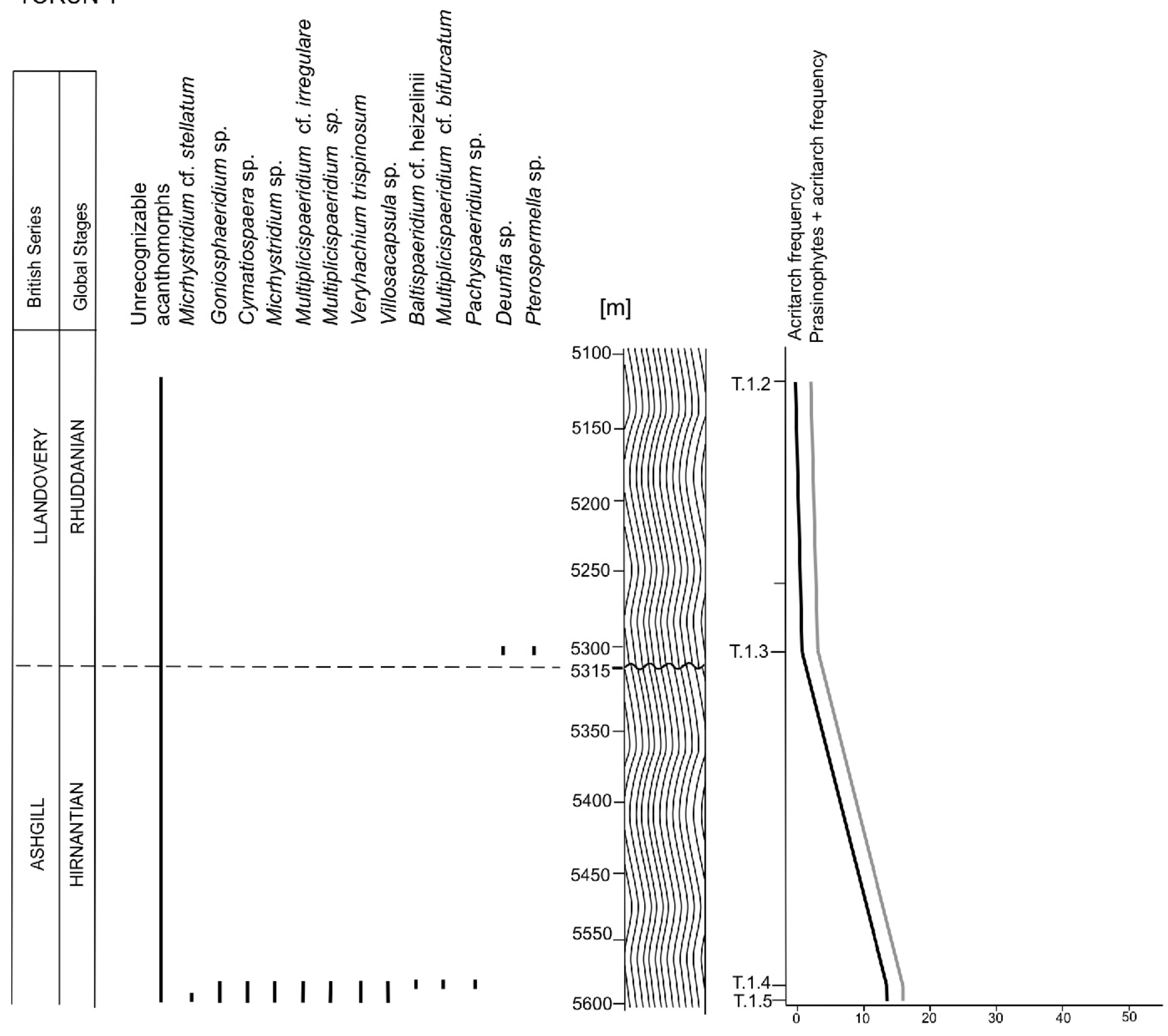

folded clastic sediments

Fig. 7. Simplified lithology and acritarch range chart, and acritarch and prasinophyte + acritarch frequency in the Torun 1 borehole

For other explanations see Figure 2

\section{LOW TO MIDDLE LATITUDES OF THE SOUTHERN HEMISPHERE}

Considering the palaeogeographical position of the main landmasses in Late Ordovician times (Fig. 1C, D), Baltica occupied subtropical latitudes between an equator and $30^{\circ} \mathrm{S}$-latitude (Torsvik and Cocks, 2004). This continent was separated from Gondwana (on the South Pole) by the Rheic Ocean. Smaller blocks, such as Avalonia, the Bohemian Massif and Małopolska Block, occupied $\sim 30^{\circ}$ S-latitude in the Late Ordovician (Cocks, 2000; Torsvik and Cocks, 2005). All these localities were placed more or less in the same climatic zone. Differences within the microphytoplankton content of deposits may results from environmental depositional conditions, such as bathymetry, influence of oceanic currents, etc.

\section{BALTICA}

Apart from the Polish localities described above, other palynological data comes from Estonia - from the Rapla borehole in northern Estonia and the Valga 10 borehole in southern Estonia.

At Rapla, where the problem of facies control on preservation of organic-walled microfossils is evident in sections spanning the O/S boundary (Uutela and Tynni, 1991), shallow-water carbonate platforms developed during the Late Ordovician. The presence of discontinuity surfaces within the boundary interval and lack of precise stratigraphic control are additional problems for this section. In the uppermost Ashgill (Hirnantian) of the Rapla borehole (Uutela and Tynni, 1991), 40 acritarch and prasinophyte species were recorded, of which 29 cross the O/S 


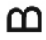
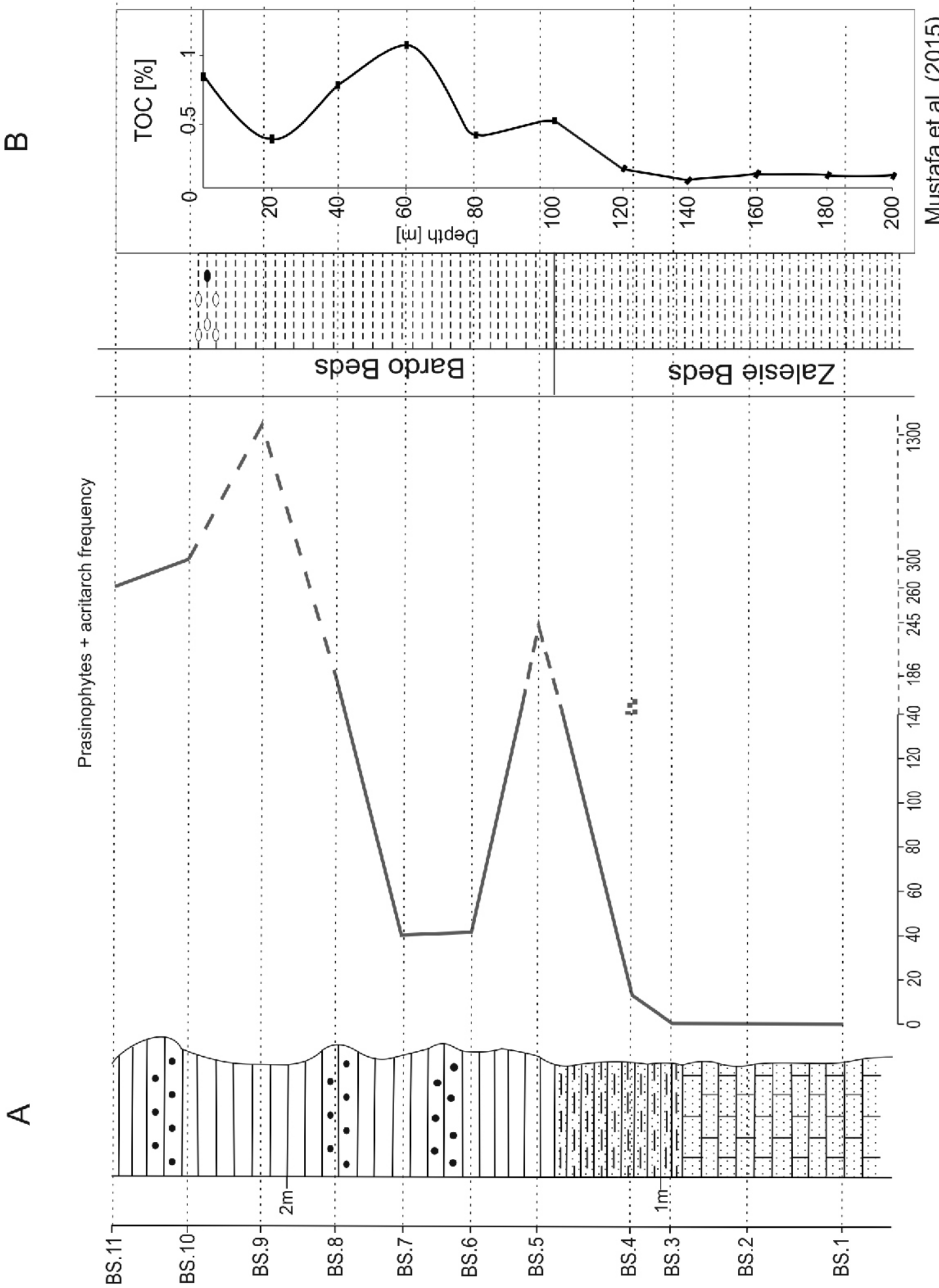

\begin{tabular}{|c|c|c|c|c|}
\hline Sł!un ןejo60이! & дәqшәш ezıqZ & 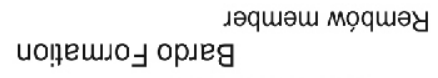 & & 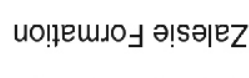 \\
\hline səuozo!̣ ןejoך & & $\begin{array}{l}\text { snłeulunoe - } \\
\text { snsuəsse }\end{array}$ & 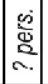 & efeuosonu \\
\hline səuozo!̣ |eqo|כ & & snłeu!unoe & $\begin{array}{l}0 \\
0 \\
\vdots \\
\vdots\end{array}$ & ереиолопи \\
\hline sәбeis ןeq이 & & N $\forall I N \forall O O \cap H Y$ & & N $\forall I \perp N \forall N Y I I H$ \\
\hline sə!ıəs ys!!!ıg & & $\wedge \forall \exists \wedge O 0 N \forall 77$ & & כורד \\
\hline
\end{tabular}


boundary. Assemblages from the Lower Silurian strata are impoverished, with only four acritarch species recorded.

In terms of the abundance, Micrhystridium sp. and Lophosphaeridium sp. are the dominant taxa. Other taxa, such as Baltisphaeridium sp, Gorgonisphaeridium sp, Leiosphaeridia spp., Stellechinatum sp., Multiplicisphaeridium sp., Tasmanites sp., Cymatiosphaera sp., Pulvinosphaeridium sp. and Estiastra sp. are rare.

Generally, the trend in the frequency of genera and species is decreasing from the uppermost Ashgill (middle Pirgu, Regional Stage) to the lowermost Silurian (lowermost Juurgu, Regional Stage; Kaljo et al., 1996: table 1 and fig. 3).The O/S boundary in the Rapla borehole is characterized by a minor discontinuity surface. In the Porkuni Regional Stage (uppermost Ashgill), acritarchs are generally absent due to both secondary dolomitization and the occurrence of high-energy sediments of reef facies (Kaljo et al., 1996).

Following the trend in the increasing/decreasing number of genera and species, it is possible to compare data from the Rapla borehole with the Polish data.

In general, the uppermost Ordovician assemblages from Poland are less numerous than those in Rapla, but the lowermost Silurian ones are more. In the Polish profiles, there are no typical shallow-water carbonate platform genera, such as Estiastra, Pulvinosphaeridium and Schismatosphaeridium.

More information comes from detailed studies on palynological investigations from the Valga 10 drill core (Delabroye et al., 2011a). The latest Ordovician/earliest Silurian deposits from this borehole of southern Estonia represent transitional environments of the Livonian Basin - a transitional basin between north Estonian carbonate shelves and deeper-water sediments of the Scandinavian Basin.

Palynological material from the Valga 10 drill core represents shallower-water deposits than those from the Baltic Depression and the southern part of the Holy Cross Mts. The investigated profile of the Valga 10 borehole involves a longer time interval - the latest Katian and Hirnantian (Ordovician) and the earliest Silurian (Delabroye et al., 2011a). The correlations with other profiles are hindered: chitinozoan biozones have not been identified; probably some redeposited assemblages occur (Delabroye et al., 2011a and references therein).

Deposits of the O/S boundary from Gotland are known from the Nar borehole. They occur at similar depths to those from the Valga 10. Stratigraphy of this interval in the Nar borehole during acritarch and prasinophyte investigation was incomplete and showed the existence of a hiatus at the O/S boundary, which included the acuminatus Zone (Le Hérissé, 1989).

It is difficult to compare quantitative data; however, table 2 in Le Hérissé (1989) shows the existence of a taxonomically diverse (14 taxa) assemblage.

The latest Katian and Hirnantian palynological assemblages were studied both in the Baltic Depression (Stempień-Sałek, 2011) and the Holy Cross Mts. (Trela and Szczepanik, 2009). In the Szumsko Kolonia borehole, drilled in the Bardo Syncline, the upper Hirnantian acritarch assemblages are similar to those from Zalesie and Bardo Stawy, although, the diversity and frequency are higher. Particularly interesting is the occurrence of taxa from the peri-Gondwanan acritarch palaeoprovince (Trela and Szczepanik, 2009).

The sample from upper Hirnantian deposits of the Szumsko Kolonia borehole contains frequent and diversified assemblages dominated by the Veryhachium taxa (70\%). This sample comes from older deposits than those described in the Bardo Stawy and Zalesie Nowe sections, and the palynological assemblages are comparable to the coeval ones from the Valga 10 borehole, although the composition is different (dominance of Veryhachachium versus cryptospores). For a full list of microphytoplankton assemblages see Delabroye et al. (2011a) and Trela and Szczepanik (2009).

The uppermost Hirnantian acritarch assemblages in the Bardo Stawy and Zalesie Nowe sections are similar to those from the Szumsko Kolonia and Valga 1 boreholes, although they are poorer.

Comparison of the earliest Silurian acritarchs is difficult because there is only one productive Rhuddanian sample from the Valga 10 drill core. This sample (Valga 10) from the lowermost Silurian contains a small and poorly diversified assemblage dominated by one morphotype of Leiosphaeridia. Such an assemblage is similar to those from the Bardo Stawy section (Fig. 2). The same peak in the frequency of Leiosphaeridia (whereas acritarchs are rare) is observed in sample BS. 5, just above the O/S boundary. A similar situation is observed in sample Z. 14 in the Zalesie Nowe section (Fig. 3). Other (younger) Silurian samples from the southern part of HCM (BS. 6-BS. 20) show a diversification trend in the palynological assemblage.

Such a diversification of acritarch assemblage disagrees with a general statement in Delabroye et al. (2011a: 33) that extremely low diversity seems to be a general feature of phytoplanktonic assemblages of the beginning of the Silurian, dominated mainly by sphaeromorphs and environmentally tolerant acritarchs. More diverse acritarch associations developed at the Rhuddanian/Aeronian transition (Duffield and Legault, 1981; Martin, 1989; Le Hérissé, 2000; Vecoli, 2008).

In our opinion, this is probably true for acritarch assemblages from deposits representing rather shallower facies, similar to those in southern Estonia (Valga 10), as well as deep basin facies, e.g. from northern Poland (Baltic Depression): Białogóra 1 and Łeba 8.

Acritarchs in the Bardo Stawy (S-HCM) section come from deposits considered (probably) deep-water sediments, but not so deep as in northern Poland. In the Bardo Stawy section, diversification of the acritarch assemblage starts in deposits of the acuminatus-ascensus Biozone. Additionally, deposits from the O/S interval of the Zalesie Nowe section come from shallower environments (Bednarczyk, 1996b; Trela, 2005, 2006; Trela and Szczepanik, 2009).

While studying the distribution of palynomorphs taxa, a clear dependence on bathymetry is observed. The dominance of prasinophytes (leiosphaeres) and crypyospores is characteristic for shallower depths. In deeper water, acanthomorphs are more abundant; they dominate in the assemblage. In the deepest environments, the dominance of leiosphaeres returns, although acantomorphs are numerous, but not as abundant as in shallower ones. Additionally, giganteus acritarchs occur in carbonate deposits (Le Hérissé, 1989). Such a pattern is generally compatible with a bathymetric model by Dorning (1981) and Al-Ameri (1983).

\section{LAURENTIA}

At the Ordovician/Silurian transition, Anticosti Island (Québec, eastern Canada) was located at low to intermediate palaeolatitudes $\left(15-30^{\circ} \mathrm{S}\right)$ on the eastern margin of Laurentia (Torsvik and Cocks, 2005; Nawrocki et al., 2007).

The uppermost Ordovician-lowermost Silurian deposits of Anticosti Island, Québec, are represented by a carbonate sequence of calcareous shales and interbedded fossiliferous limestones, shales and bioherms that were deposited in shallow to deep subtidal environments. In different sections of Anticosti Island, the O/S boundary is drawn within different types of sediments (Barnes, 1988). 
Very interesting palynological data on Hirnantian acritarchs from Anticosti were published by Delabroye et al. (2011b). These authors observed a post-crisis, low diversity acritarch assemblage dominated by large forms typical of carbonate platforms, as well as long-ranging taxa and cryptospores (land-derived), while typical Ordovician taxa (Ordovicidium spp., Baltisphaeridium spp., Peteinosphaeridium spp.) were not recorded.

At Anticosti, the O/S boundary sections are characterized by scant biostratigraphic control (lack of graptolite fauna) and the presence of palynologically barren strata (e.g., bioherm beds above the systemic boundary; Martin, 1988). This hinders the analysis of microphytoplankton diversity trends.

\section{CHINESE BLOCK}

In the Zhejiang Province of South China, continuous Ordovician-Silurian transitional strata are characterized by low diversity and unfavourable preservation of palynomorphs. There is no clear change in the acritarch palynoflora across the Ordovician/Silurian boundary. The presence of abundant cryptospores may suggest a near-shore marine environment during latest Ordovician-earliest Silurian times. Acritarchs become abundant and well preserved $400 \mathrm{~m}$ above the accepted Ordovician/Silurian boundary. The insufficiency of detailed investigation of microphytoplankton at the O/S boundary, due to sparse sampling along the thick section, is the major obstacle of this section (Yin and He, 2000).

\section{HIGH PALAEOLATITUDES OF THE SOUTHERN HEMISPHERE}

\section{BOHEMIAN MASSIF (PERUNICA)}

The high-latitude palaeogeograpic position of the Bohemian Massif at the O/S transition, shown by Delabroye et al. (2011a), is accepted herein (Fig. 1C). According to that paper, the Bohemian Massif is classified as a terrain adjacent to Northern Gondwana.

The Ordovician-Silurian boundary in the Prague Basin is identified in two continuous sections (Dufka and Fatka, 1993). Both sections are well-dated by means of graptolites (Štroch, 1986). The O/S boundary interval is characterized there by a transition from flysch-type deposits into black graptolitic shales The dark shales with graptolites appear already below the base of the ascensus Biozone and they correspond probably to the uppermost part of the persculptus Biozone (similar situation to the southern part of the Holy Cross Mts.). The weakness of this section for palynological investigations is the absence of acritarchs and prasinophytes from the base of the Llandovery. Acritarchs were recorded only from the green-grey claystone of the upper part of the acuminatus graptolite Biozone - $1.2 \mathrm{~m}$ above the boundary (Dufka and Fatka, 1993).

\section{GONDWANA}

In Saudi Arabia, well-established chitinozoan zones could be correlated with the graptolite zonation of the British Standard. The systemic interval - persculptus and the lower part of the acuminatus graptolite biozones - is characterized by low diversity of microphytoplankton. The organic-rich black shales ("Hot Shales") from the middle and upper part of the acuminatus graptolite Biozone are particularly unfavourable for acritarchs and prasinophytes. Only some cryptospores were found
(Spina, 2015). However, it is important to note that this zone is not sufficiently investigated. For full understanding of the recovery pattern of microphytoplankton, it is important to study the silty intercalation and clays within the black graptolitic shales (Le Hérissé, 2000).

Some interesting data come from the Tt1 borehole Ghadamis Basin, southern Tunisia (Vecoli et al., 2009). "There is no evidence of the major discontinuity at the Ordovician/Silurian boundary even the sequence is condensed", as stated by Vecoli et al. (2009), and the Silurian begins from the vesiculosus Biozone. The ascensus-acuminatus Biozone is not present there.

In NE Algerian Sahara (borehole NI-2) the profile is not continuous across the O/S boundary and is characterized by an important gap comprising most of the upper part of the Ordovician and the whole Llandovery. This hiatus caused the Wenlock black shales to overlie directly the Hirnantian sediments (Paris et al., 2000). Other localities (Chad) from northern Africa are not well controlled stratigraphically (Le Hérissé et al., 2013).

\section{MICROPHYTOPLANKTON ABUNDANCE AND TOTAL ORGANIC CARBON}

Organic matter is primarily defined as derived from the accumulation and preservation of organic compounds that directly or indirectly come from cells or tissues of living organisms. In the case of shale rocks, the TOC content is influenced not only by phytoplankton (e.g., acritarchs and prasinophytes in the present study) but also by graptolites, algae and other organisms.

The total organic carbon content in rocks from the Bardo Stawy section was studied by Mustafa et al. (2015). It is very interesting to compare the microphytoplankton (prasinophyte and acritarch) abundance with the TOC curve in the same time interval (Fig. 9). Similar comparison of TOC and acritarch and prasinophyte abundance was presented by Vecoli et al. (2009), but the Silurian in the borehole from the Ghadamis Basin begins from the vesiculosus Biozone. In the Bardo Stawy section, the O/S transiton is continuous so that the data obtained from the ascensus-acuminatus Biozone gives a fuller picture of changes on the boundary of these two systems. The prasinophyte and acritarch abundance and the TOC trend are very similar in the uppermost Ordovician deposits (low values). From the beginning of the Silurian, the TOC and acritarch-prasinophyte curves show a general increasing trend, although both curves demonstrate variations. Deviations of both curves are concordant in the lower part of the ascensus-acuminatus Biozone, but they are opposite in its upper part (Fig. 9).

It is very probable that that time another source of organic carbon played a significant role. It is highly possible that this role was played by graptolites during the post-Hirnantian glaciation biotic recovery phase.

The comparison of the TOC and microphytoplankton curves was possible only for sediments from the Bardo Stawy regarding our available data. Preliminary data are propitious and it is worth to continue such investigations.

\section{CONCLUSIONS}

1. Acritarch and prasinophyte assemblages at the Ordovician/Silurian boundary appear to be good indicators of climatic 


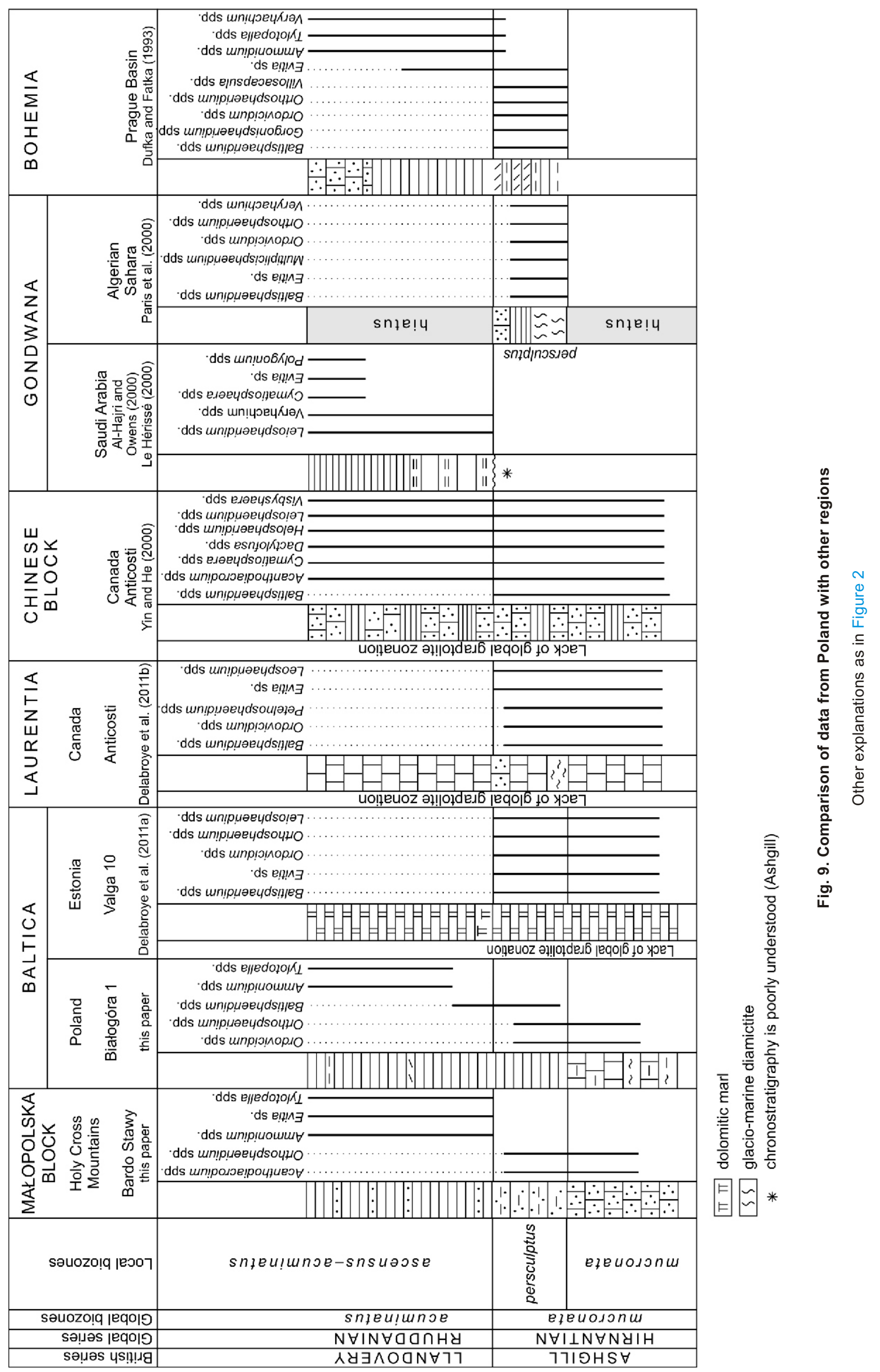


changes connected with deglaciation of Gondwana and associated glacioeustatic changes.

2. There are only a few known palynomoprh-yielding profiles with a continuous O/S transition. The profiles from Poland, especially from the Holy Cross Mts., are very good for investigations of global climatic and eustatic events in the latest Ordovician to earliest Silurian, recorded in palynological assemblages.

3. Bathymetry played the key role in taxonomic diversification of the microphytoplankton assemblages, which supports the existing models of distribution (e.g., Al-Ameri, 1983).

4. Dominance of prasinophytes (leiospheres) and crypotospores is characteristic for shallow-water environments In deeper water, dominance of acanthomorphs is observed. In the deepest-water zones - mixed assemblages occurred. The model presented in Delabroye et al. (2011b) has been verified only in the shallower environments.

5. The analysis of acritarch diversity trends vs. Total Organic Carbon (TOC) profiles shows parallel trends through the section: a low value in the Upper Ordovician and an increasing trend from the beginning of the Silurian. Opposite deviations on the TOC and arcitarch-prasinophyte abundance curves may indicate that other organisms significantly contributed to the accumulation of organic carbon in sediments during that time.

Acknowledgements. The authors are greatly indebted to the reviewers: T. Servais (French National Centre for Scientific Research) and M. Vecoli (Saudi Arabian Oil Company) for their valuable comments on our text.

\section{REFERENCES}

Al-Ameri, T., 1983. Acid-resistant microfossils used in the determination of Palaeozoic palaeoenvironments in Libya. Palaeogeography, Palaeoclimatology, Palaeoecology, 44: 103-116.

Al-Hajri, S.A., Owens, B., 2000. Sub-surface palynostratigraphy of the Palaeozoic of Saudi Arabia. GeoArabia Special Publication 1: 10-17. Gulf PetroLink, Bahrain

Armstrong, H.A., 1996. Biotic recovery after mass extinction: the role of climate and ocean-state in the post-glacial (Late Ordovician-Early Silurian) recovery of the conodonts. Geological Society Special Publications, 102: 105-117

Armstrong, H.A., 2007. On the cause of the Ordovician glaciation In: Deep-Time Perspectives on Climate Change: Marrying the Signal from Computer Models and Biological Proxies (eds. M Williams, A.M. Haywood, F.J. Gregory and D.N. Schmidt) 101-121. The Micropal. Soc.

Armstrong, H.A., Harper, D.A.T., 2014. An earth system approach to understanding the end-Ordovician (Hirnantian) mass extinction. GSA Special Paper, 505: 287-300.

Barnes, C.R., 1988. The proposed Cambrian-Ordovician globa boundary stratotype and point (GSSP) in western Newfoundland, Canada. Geological Magazine, 125: 381-414.

Bednarczyk, W., 1968. The Ordovician in the region of Kętrzyn (NE Poland) (in Polish with English summary). Acta Geologica Polonica, 29: 409-442

Bednarczyk, W., 1971. The Ordovician of the eastern part of the Podlasie depression (in Polish with English summary). Acta Geologica Polonica, 21: 201-222.

Bednarczyk, W., 1974. The Ordovician in the Koszalin-Chojnice region (Western Pomerania). Acta Geologica Polonica, 24: 581-600.

Bednarczyk, W., 1981. Stratygrafia ordowiku Gór Świętokrzyskich (in Polish). Przewodnik 53 Zjazdu Polskiego Towarzystwa Geologicznego Kielce 6-8.09.1981 (ed. H. Żakowa): 35-41. Wydawnictwa Geologiczne, Warszawa.

Bednarczyk, W., 1996a. Ordovician conodont stratigraphy in the Polish part of the Baltic Syneclise. Palaeontologica Polonica, 58: $107-121$.

Bednarczyk, W., 1996b. Zalesie. In: Sixth European Conodont Symposium (ECOS VI) (eds. M. Szulczewski and S. Skompski), Excursion Guide: 18-21.

Bednarczyk, W., 1998. Ordovician conodont biostratigraphy of the Polish part of the Baltic Syneclise. Palaeontologia Polonica, 58 : 107-121.

Bednarczyk, W., 1999. Chitinozoa-bearing horizons in the Ordovician of Northern Poland in the light of conodont stratigraphy. Bulletin of the Polish Academy of Sciences, Earth Sciences, 47 $1-13$.
Bednarczyk, W., Hints, L., Podhalańska, T., 1996. Late Ashgillian (Hirnantian) in Poland. In: The third Baltic Stratigraphical Conference. Abstrats. Field Guide (eds. T. Meilda, I. Puura, J. Nemliher, A. Raukas and L. Saarse). Tartu.

Belka, Z., Ahrendt, H., Franke, W., Wemmer, K., 2000. The Baltica-Gondwana suture in central Europe: evidence from $\mathrm{K}-\mathrm{Ar}$ ages of detrital muscovites and biogeographical data. Geological Society Special Publications, 179: 87-102.

Beuf, S., Bennacef, A., Biju-Duval, B., De Charpal, O., Gariel, O. Rognon, P., 1971. Example of Cratonic Sedimentation: Lower Paleozoic of Algerian Sahara. AAPG Bulletin, 55: 2225-2245.

Berry, W.J., Ankley, G.T., Di Toro, D.M., Hansen, D.J., 1996. Assessing the ecological risk of metals in sediments. Environmental, Toxicology and Chemistry, 15: 2053-2055.

Brechley, P.J., 1988. Environmental changes close to the Ordovician-Silurian boundary. Bulletin of the British Museum of Natural History (Geology), 43: 377-385.

Cocks, L.R.M., 2000. The early Paleozoic geography of Europe. Journal of the Geological Society, 157: 1-10.

Cocks, L.R.M., Torsvik, T.H., 2002. Earth geography from 500 to 400 million years ago: a faunal and palaeomagnetic review. Journal of the Geological Society, 159: 631-644.

Cocks, L.R.M., Torsvik, T.H., 2005. Baltica from the late Precambrian to mid-Palaeozoic times: the gain and loss of a terrane's identity. Earth-Science Reviews, 72: 39-66.

Dadlez, R., 1978. Sub-Permian rock complexes in the Koszalin-Chojnice Zone (in Polish with English summary). Kwartalnik Geologiczny, 22 (2): 269-302.

Dadlez, R., 1982a. Permian-Mesozoic tectonics versus basement fractures along the Teisseyre-Tornquist Zone in the territory of Poland (in Polish with English summary). Kwartalnik Geologiczny, 26 (2): 273-284.

Dadlez, R., 1982b. On interpretation of lower Paleozoic sequence from the borehole column Torun 1 (in Polish with English summary). Przegląd Geologiczny, 30: 273-276.

Dadlez, R., 1993. Pre-Cenozoic tectonics of the southern Baltic Sea. Geological Quarterly, 37 (3): 431-450.

Dadlez, R., 2000. Pomeranian Caledonides (NW Poland), fifty years of controversies: a review and a new concept. Geologica Quarterly, 44 (3): 221-236.

Dadlez, R., Kowalczewski, Z., Znosko, J., 1994. Some key problems of the pre-Permian tectonics of Poland. Geological Quarterly, 38 (2): 169-190.

Delabroye, A., Vecoli, M., Hints, O., Servais, T., 2011a. Acritarchs from the Ordovician-Silurian boundary beds of the Valga-10 drill core, southern Estonia (Baltica) and their stratigraphical and palaeobiogeographical implications. Palynology, 35: 4-45. 
Delabroye, A., Munnecke, A., Vecoli, M., Copper P., Tribovillard, N., Joachimski, M.M., Desrochers, A., Servais, T., 2011b. Phytoplankton dynamics across the Ordovician/Silurian boundary at low palaeolatitudes: Correlations with carbon isotopic and glacial events. Palaeogeography, Palaeoclimatology, Palaeoecology, 312: 79-97.

Dorning, K.J., 1981. Silurian acritarchs from the type Wenlock and Ludlow of Shropshire, England. Review of Palaeobotany and Palynology, 34: 175-203.

Dufka, P., Fatka, O., 1993. Chitinozoans and acritarchs from the Ordovician-Silurian boundary of the Prague Basin, Czech Republic. Special Papers in Palaeontology, 48: 17-28.

Duffield, S.L., Legault, J.A., 1981. Acritarch biostratigraphy of Upper Ordovician-Lower Silurian rocks, Anticosti Island, Quebec: preliminary results. Stratigraphy and Paleontology, 2: 91-99.

Finney, S.C., Cooper, J.D., Berry, W.B.N., 1997. Late Ordovician mass extinction: sedimentologic, cyclostratigraphic and biostratigraphic records from platform and basin succession in central Nevada. BYU Geology Studies, 42: 79-103.

Jablonski, D., 1991. Extinctions: a paleontological perspective. Science, 253: 754-757.

Jachowicz, M., 2000. Acritarch assemblages from the Silurian Pomeranian Caledonides and their foreland. Geological Quarterly, 44 (3): 317-331.

Jaworowski, K., 2000. Facies analysis of the Silurian shalesiltstone succession in Pomerania (northern Poland). Geological Quarterly, 44 (3): 297-317.

Kaljo, D., 1996. Late Ordovician-Early Silurian succession of paleoecosystems inh Estonia. Paleontological Journal, 30: 693-700.

Kaljo, D., Hints, L., Männik, P., Nölvak, J., 2008. The sussession of Hirnantian events based on data from Baltica: brachiopods, chitinozoans, conodonts and carbon isotopes. Estonian Journal of Earth Sciences, 57: 197-218.

Karnkowski, P.H., 2008. Tectonic subdivision of Poland: Polish Lowlands (in Polish with English summary). Przegląd Geologiczny, 56: 895-903.

Kielan, Z., 1956. On the stratigraphy of the Upper Ordovician in the Holy Cross MTS (in Polish with English summary). Acta Geologica Polonica, 6 : 253-272.

Kielan, Z., 1959. Upper Ordovician trilobites from Poland and some related forms from Bohemia and Scandinavia. Palaeontologia Polonica, 11.

Kremer, B., 2001. Acritarchs from the Upper Ordovician of southern Holy Cross Mountains, Poland. Acta Palaeontologica Polonica, 46: 595-601.

Krzemiński, L., Poprawa, P., 2006. Geochemistry of the clastic deposits of the Ordovician and Silurian deposits from the Koszalin-Chojnice Zone and the western part of the Baltic Basin (in Polish with English summary). Prace Państwowego Instytutu Geologicznego, 186: 123-148.

Le Hérissé, A., 1989. Acritarches et kystes d'algues Prasinophycées du Silurien de Gotland, Suède. Palaeontographia Italica, 76: 57-302.

Le Hérissé, A., 2000. Characteristics of the acritarch recovery in the early Silurian of Saudi Arabia. GeoArabia Special Publication, 1 57-81. Gulf PetroLink, Bahrain.

Le Hérissé, A., Paris, F., Steemans, P., 2013. Late Ordovician-earliest Silurian palynomorphs from northern Chad and correlation with contemporaneous deposits of southeastern Libya. Bulletin of Geosciences, 88: 483-504.

Lewandowski, M., 1993. Paleomagnetism of the Paleozoic rocks of the Holy Cross Mts (Central Poland) and the origin of the Variscan Orogeny. Publications of the Institute of Geophysics. Polish Academy of Sciences, 23: 1-85.

Martin, F., 1988. Late Ordovician and Early Silurian acritarchs. Bulletin of the British Museum (Natural History), London, Geology Series, 43: 299-309.

Martin, F., 1989. Silurian fossils in stratigraphy: 29. Acritarchs. Natural Museum Wales, Cardiff, Geological Service, 9: 207-215.

Masiak, M., Podhalańska, T., Stempień-Sałek, M., 2003. Ordovician-Silurian boundary in the Bardo Synkline, Holy Cross
Mountains, Poland - new data on fossil assemblages and sedimentary succession. Geological Quarterly, 47 (4): 311-330.

Miller, A.I., 1997. Comparative diversification dynamics among palaeocontinents during the Ordovician Radiation. Geobios, Mémoire Spécial, 20: 397-406.

Miller, A.I., Mao, S., 1995. Association of orogenic activity with the Ordovician radiation of marine life. Geology, 23: 305-308.

Modliński, Z., 1968. Ordovician in the western Pomerania (in Polish with English summary). Kwartalnik Geologiczny, 12 (3): 488-492.

Modliński, Z., 1978. The distribution of the pyroclastic deposits in the Ordovician of the Polish Lowland (in Polish with English summary). Kwartalnik Geologiczny, 22 (1): 49-58.

Modliński, Z., 1987. Ordowik (in Polish with English summary). Prace Instytutu Geologicznego, 119: 10-12.

Modliński, Z., 1988. Development of Ordovician sediments in Pomerania and adjacent Baltic Basin (in Polish with English summary). Kwartalnik Geologiczny, 32 (3/4): 565-576.

Modliński, Z., ed., 2010. Paleogeological atlas of the sub-Permian Paleozoic of the East-European Craton in Poland and neighboring areas. PIG-NRI, Warszawa.

Modliński, Z., Szymański, B., 1997. The Ordovician lithostratigraphy of the Peribaltic Depression (NE Poland). Geological Quarterly, 41 (3): 273-288.

Modliński, Z., Szymański, B., 2008. Ordowik (in Polish). Profile Głębokich Otworów Wiertniczych Państwowego Instytutu Geologicznego, 123: 46-52, 128-131.

Modliński, Z., Szymański, B., Teller, L., 2006. The Silurian lithostratigraphy of the Polish part of the Peri-Baltic Depression (N Poland) (in Polish with English summary). Przegląd Geologiczny, 54: 787-796.

Modliński, Z., Jacyna, J., Kanev, S., Khubldikov, A., Laskova, L., Laskvas, J., Lendzion, K., Mikazane, I., Pomeranceva, R., 1999. Palaeotectonic evolution of the Baltic Syneclise during the Early Palaeozoic as documented by palaeothickness maps. Geological Quarterly, 43 (3): 285-296.

Mustafa, K.A., Sephton, M.A., Watson, J.S., Spathopoulos, F., Krzywiec, P., 2015. Organic geochemical characteristics of black shales across the Ordovician-Silurian boundary in the Holy Cross Mountains, central Poland. Marine and Petroleum Geology, 66: 1042-1055.

Narkiewicz, M., 2002. Ordovician through earliest Devonian development of the Holy Cross Mts. (Poland): constraints from subsidence analysis and thermal maturity data. Geological Quarterly, 46 (3): 255-266.

Nawrocki, J., Poprawa, P., 2006. Development of Trans-European Suture Zone in Poland: from Ediacaran rifting to Early Palaeozoic accretion. Geological Quarterly, 50 (1): 5-76.

Nawrocki, J., Dunlap, J., Pecskay, Z., Krzemiński, L., Żylińska, A., Fanning, M., Kozłowski, W., Salwa, S., Szczepanik, Z., Trela, W., 2007. Late Neoproterozoic to Early Palaeozoic palaoegeography of the Holy Cross Mountains (Central Europe): an integrated approach. Journal of the Geological Society, 164: 405-423.

Nehring, M., 1969. Ordovician conodonts in borehole Ketrzyn (in Polish with English summary). Kwartalnik Geologiczny, 13 (1): 27-42

Page, A., Zalasiewicz, J., Willams, M., Popov, L.E., 2007. Were transgressive black shales a negative feedback modulating glacioeustacy in the Early Palaeozoic Icehouse? In: Deep Time Perspectives on Climate Change: Marrying the Signal from Computer Models and Biological Proxies (eds. M. Williams, A.M.Haywood, F.J. Gregory and D.N. Schmidt): 123-156. The Micropal. Soc.

Paris, F., Bourahrouh, A., Le Hérissé, A., 2000. The effects of the final stages of the Late Ordovician glaciation on marine palynomorphs (chitinozoans, acritarchs, leiospheres) in well NI-2 (NE Algerian Sahara). Review of Palaeobotany and Palynology, 113: 87-104.

Paris, F., Hérissé, A., Monod, O., Kozlu, H., Ghienne, J.-F., Dean, W., Vecoli, M., Günay, Y., 2007. Ordovician chitinozoans and acritarchs from southern and southeastern Turkey. Revue de Micropaléontologie, 50: 81-107. 
Pharaoh, T.C., 1999. Palaeozoic terranes and their lithospheric boundaries within the Trans-European Suture Zone (TESZ): a review. Tectonophysics, 314: 17-41.

Podhalańska, T., 1980. Stratigraphy and facial development of Middle and Upper Ordovician deposits in the Łeba Elevation (NW Poland). Acta Geologica Polonica, 30: 327-390.

Podhalańska, T., 1999. The Upper Ordovician and the lower Silurian in the Peribaltic depression: stratigraphy and development. Acta Universitatis Carolinae Geology, 43: 221-224.

Podhalańska, T., 2003a. Late Ordovician to early Silurian transition and the graptolites from Ordovician/Silurian boundary near the SW rim of the East European Craton (northern Poland). Serie Correlción Geológica, 18: 165-171.

Podhalańska, T., 2003b. The Ordovician/Silurian boundary graptolithic biozonation and chronostratigraphy: problems and new ideas (in Polish with English summary). Przegląd Geologiczny, 51: 942-946.

Podhalańska, T., 2007. Ichnofossils from the Ordovician mudrocks of the Pomeranian part of the Teisseyre-Tornquist Zone (NW Poland). Palaeogeography, Palaeoclimatology, Palaeoecology, 245: 295-305.

Podhalańska, T., 2009. Distribution of microfossils in the Upper Ordovician and lowest Silurian from eastern part of the Baltic Basin with implications for the Hirnantian climatic changes. 7th Micropaleoontological Workshop Mikro-2009, Św. Katarzyna Abstract and Excursion Guide (eds. D. Peryt and M.A Kamiński): 60.

Podhalańska, T., Modliński, Z., 2006. Stratigraphy and facies characteristics of the Ordovician and Silurian deposits of the Koszalin-Chojnice zone; similarities and differences to the western margin of the East European Craton and Rügen area (in Polish with English summary). Prace Państwowego Instytutu Geologicznego, 186: 39-78.

Poprawa, P., 2006. Development of the Caledonian collision zone along the western margin of Baltica and its relation to the foreland basin (in Polish with English summary). Prace Państwowego Instytutu Geologicznego, 186: 189-213.

Przybyłowicz, T., 1980. Petrography of the Ordovician pyroclastic sediments in the Łeba Elevation area (in Polish with English summary). Archiwum Mineralogiczne, 36: 73-81.

Raup, D.M., Sepkoski, J.J., Jr., 1982. Mass extinctions in the marine fossil record. Science, 215: 1501-1503.

Rong, J., Chen., X., Harper, D.A.T., 2002. The latest Ordovician Hirnantia Fauna (Brachiopoda) in time and space. Lethaia, 35 : 231-249.

Samuelsson, J., Vecoli, M., Bednarczyk, W., Verniers, J., 2002 Timing of the Avalonia-Baltica plate convergence as inferred from palaeogeographic and stratigraphic data of chitinozoan assamblages in west Pomerania, northern Poland. Geological Society Special Publications, 201: 95-113.

Sepkoski, J.J.Jr, 1996. Patterns of Phanerozoic Extinction: a Perspective from Global Data Bases. In: Global Events and Event Stratigraphy in the Phanerozoic (ed. O.H. Walliser): 35-51. Springer, Berlin, Heidelberg.

Servais, T., Lehnert, O., Li, J., Mullins, G.L., Munnecke, A. Nützel, A., Vecoli, M., 2008. The Ordovician Biodiversification: revolution in the oceanic trophic chain. Lethaia, 41: 99-109.

Spina, A., 2015. Latest Ordovician (Hirnantian) miospores from the NL-2 well, Algeria, North Africa, and their evolutionary significance. Palynology, 39: 205-219.

Stempień-Sałek, M., 2011. Palynomorph assemblages from the Upper Ordovician in northern and central Poland. Annales Societatis Geologorum Poloniae, 81: 21-61.

Štroch, P., 1986. Ordovician-Silurian boundary in the Prague Basin (Barrandian area, Bohemia). Sborník geologických věd, Geologie, 41: 69-103.

Szczepaniak, Z., 2000. The Ordovician acritarchs of the Pomeranian Caledonides and their foreland - similarities and differences. Geological Quarterly, 44 (3): 275-295.

Tait, J.A., Bachtadse, V., Franke, W., Soffel, H.C., 1997 Geodynamic evolution of the European Variscan fold belt: palaeomagnetic and geological constraints. Geologische Rundschau, 86: 585-598.
Teller, L., 1974. The Silurian of the margin of the East European platform in the region of Miastko-Chojnice (NW Poland). Acta Geologica Polonica, 24: 563-580.

Teller, L., Korejwo, K., 1968. Lower Silurian deposits from the borehole Lutom 1 (North-Eastern Poland) (in Polish with English summary). Acta Geologica Polonica, 18: 293-301.

Tomczyk, H., 1962. Stratigraphic problems of the Ordovician and Silurian in Poland in the light of recent studies (in Polish with English summary). Prace Instytutu Geologicznego, 35: 1-134.

Tomczyk, H., 1968. Silurian stratigraphy in the Peribaltic areas of Poland based on drilling data (in Polish with English summary). Kwartalnik Geologiczny, 12 (1): 15-36.

Tomczyk, H., 1987. Korelacja tektoniczno-strukturalna brzegu platformy wschodnioeuropejskiej z regionem świętokrzyskim (epoka kaledońsko-waryscyjska) (in Polish). Kwartalnik Geologiczny, 31 (2/3): 486-488.

Tomczykowa, E., 1964. Ordovician of the East-European Platform in the area of Poland (in Polish with English summary). Kwartalnik Geologiczny, 8 (3): 491-505

Torsvik, T.H., Cocks, L.R.M., 2004. Earth geography from 400 to $250 \mathrm{Ma}$ : a palaeomagnetic, faunal and facies review. Journal of the Geological Society, 161: 555-572.

Torsvik, T.H., Cocks, L.R.M., 2005. Norway in space and time: a centennial cavalcade. Norwegian Journal of Geology, 85: 73-86.

Torsvik, T.H., Cocks, L.R.M, 2013. Gondwana from top to base in space and time. Gondwana Research, 24: 999-1030.

Torsvik, T.H., Carlos, D., Mosar, J., Cocks, L.R.M., Malme, T. 2002. Global reconstructions and North Atlantic palaeogeography 400 Ma to Recent. In: Batlas - Mid Norway plate reconstructions atlas with global and Atlantic perspectives (ed. E.A. Eide): 18-39. Geological Survey of Norway.

Trela, W., 2005. Sedimentary environment in the upper Ordovician in the Kielce region of the Holy Cross Mts (in Polish with English summary). Biuletyn Państwowego Instytutu Geologicznego, 417: 109-154

Trela, W., 2006. Lithostratigraphy of the Ordovician in the Holy Cross Mountains (in Polish with English summary). Przegląd Geologiczny, 54: 622-631.

Trela, W., Szczepanik, Z., 2009. Lithology and acritarch assemblage of the Zalesie Formation in the Holy Cross Mountains in relation to the Late Ordovician paleogeography and sea-level changes (in Polish with English summary). Przegląd Geologiczny, 57: 147-157

Uutela, A., Tynni, R., 1991. Ordovician acritarchs from the Rapla borehole, Estonia. Geological Survey of Finland Bulletin, 353: $1-135$.

Vecoli, M., 2008. Fossil microphytoplankton dynamics across the Ordovician-Silurian boundary. Review of Palaeobotany and Palynology, 148: 91-107.

Vecoli, M., Riboulleau, A., Versteegh, G.J.M., 2009. Palynology, organic geochemistry and carbon isotope analysis of a latest Ordovician trought Silurian clastic succession from borehole Tt1, Ghadamis Basin, southern Tunisia, North Africa: palaeoenviromental interpretation. Palaeogeography, Palaeoclimatology, Palaeoecology, 273: 378-394.

Wrona, R., Bednarczyk, W.S., Stempień-Sałek, M., 2001. Chitinozoas and acritarchs from the Ordovician of the Skibno 1 borehole, Pomerania, Poland: implications for stratigraphy and palaeogeography. Acta Geologica Polonica, 51: 317-331.

Wood, G., Gabriel, A.M., Lawson, J.C., 1996. Chapter 3. Palynological techniques - processing and microscopy. American Association of Stratigraphic Palynologists Foundation, 1: 29-50

Yin, L., He, S., 2000. Palynomorphs from the transitional sequences between Ordovician and Silurian of northwestern Zhejiang, South China. Palynofloras and Palynomophs of China: 186-202.

Żelaźniewicz A., Aleksandrowski, P., Buła, Z., Karnkowski, P., H., Konon, A., Oszczypko, N., Ślączka, A., Żaba, J., Żytko, K., 2011. Regionalizacja tektoniczna Polski (in Polish). Wydawca Wrocław: Komitet Nauk Geologicznych PAN. 